\title{
No Right to PERform a CONTRACT?
}

\author{
MARGarida Lima Rego*
}

ABSTRACT: This thesis offers an alternative outlook on the decision of a contractual party to reject the benefit of the contract when he is no longer interested in the other party's performance. It is an attempt to justify such course of action by challenging the proposition that one is always entitled to perform one's own contractual promises. This shall be done in the context of the controversial decision of the House of Lords in White \& Carter (Councils) v McGregor [1962] AC 413, a case where the insistent performer happened to be able to complete his part of the contract without the need for his customer's cooperation and even against his expressed will.

In a large number of cases the provider of a service will have no other interest in actually performing his part of the contract beyond that of securing his right to the full contract price. This thesis argues that whenever that is the case the courts should acknowledge both the service recipient's right to renounce the benefit of the contract and his power to prevent the unwanted supply of services, whether by words or conduct. The service provider who has been discharged from his duty to perform will be adequately protected so long as his right to the full contract price is not at stake. He has no need for a 'right to perform' in its proper sense.

However, he should not end up better off than he would have been had he actually performed his part of the contract. Therefore, the abdicating party should be allowed to deduct from the contract price by way of set-off whichever sums the former has saved or otherwise made as a consequence of his early release.

TAble of Contents: List of Abbreviations. Table of cases. Preliminary Chapter. Chapter One - The promissory approach to cooperation. A. A duty to cooperate? B. Protecting the parties' reasonable expectations. C. Hidden assumptions. D. An improper overgeneralisation of authority. E. Discharge through lack of cooperation. F. The concept of a 'burden'. Chapter Two - A conditional approach to cooperation. A. Contractual risk-allocation. B. Introducing the concept of condition. C. A discretionary power to cooperate? D. The obsta-

* Worcester College, Oxford. Thesis submitted in Trinity Term 2001 for the degree of Master of Philosophy.

I should like to thank Professor FMB Reynolds for his precious guidance at the early stages of my study at Oxford and my supervisor Dr S Whittaker for his considerable support during the research for, and writing of, this thesis.

This work has been funded by Fundação para a Ciência e a Tecnologia (PRAXIS XXI/BD/ 121235/99) with the additional financial support of the British Council Chevening Awards and of the Worcester College Martin Senior Scholarship, for which thanks are also due. 


\section{MARgarida Lima Rego}

cle: a right to perform. E. The hidden assumption strikes again. F. P's expectation to the full contract price. G. What exactly is at stake here? $\mathrm{H}$. What the parties have truly promised to do. Chapter Three - The right to reject the benefit of the contract. A. What if no cooperation is needed? B. The doctrine of anticipatory breach of contract. C. Missing the point. D. Yet another hidden assumption. E. The right to renounce the benefit of a contract. F. Prevention by notification. G. 'No legitimate interest, financial or otherwise'. Chapter Four - Deducting from the full contract price. A. The need for a deduction. B. How to deduct: mitigation. C. The way to do it: transaction set-off. D. What if it is cheaper to supply the services than not to? Conclusion. Bibliography.

\section{LIST OF ABBREVIATIONS}

$\begin{array}{ll}\text { AdelLRev } & \text { Adelaide Law Review } \\ \text { affd } & \text { affirmed } \\ \text { BrJLSoc } & \text { British Journal of Law and Society } \\ \text { CanBarRev } & \text { Canadian Bar Review } \\ \text { CanBLJ } & \text { Canadian Business law Journal } \\ \text { ColLRev } & \text { Columbia Law Review } \\ \text { HarvLRev } & \text { Harvard Law Review } \\ \text { JCL } & \text { Journal of Contract Law } \\ \text { JLSoc } & \text { Journal of Law and Society } \\ \text { JLegSt } & \text { Journal of Legal Studies } \\ \text { JurRev } & \text { Juridical Review } \\ \text { MelULRev } & \text { Melbourne University Law Review } \\ \text { NZULRev } & \text { New Zealand Universities Law Review } \\ \text { NwULRev } & \text { Northwestern University Law Review } \\ \text { P } & \text { service provider } \\ \text { R } & \text { service recipient } \\ \text { RLR } & \text { Restitution Law Review } \\ \text { RLJ } & \text { Revista de Legislação e Jurisprudência } \\ \text { SALJ } & \text { South African Law Journal } \\ \text { StanLRev } & \text { Stanford Law Review } \\ \text { SBFDUC } & \text { Suplemento do Boletim da Faculdade de Direito da Universidade de Coimbra } \\ \text { TulLRev } & \text { Tulane Law Review } \\ \text { UChiLRev } & \text { University of Chicago Law Review } \\ \text { UWAusLRev } & \text { University of Western Australia Law Review } \\ \text { VaLRev } & \text { Virginia Law Review } \\ & \end{array}$


Ali Shipping Corp v Shipyard Trogir [[1999] 1 WLR 314 (CA); [1998] 2 All ER 136 (CA); [1998] 1 Lloyd's Rep 711 (CA)

Alpha Trading Ltd y Dunnshaw-Patten Ltd [1981] QB 290 (CA); [1981] 2 WLR 169 (CA); [1981] 1 All ER 482 (CA); [1981] 1 Lloyd's Rep 122 (CA) ..............

Anglo-African Shipping Co of New York Inc v J Mortner Ltd [1962] 1 Lloyd's Rep 81; affd at $610(\mathrm{CA})$

Aries Tanker Corp v Total Transport Ltd [1977] 1 WLR 185 (HL); [1977] 1 All ER 398 (HL); [1977] 1 Lloyd's Rep 334 (HL)

Asamera Oil Corp v Sea Oil Corp (1979) 89 DLR (3d) 1

Astilleros Canarios SA v Cape Hatteras Shipping Co Inc and Hammerton Shipping Co SA (The Cape Hatteras) [1982] 1 Lloyd's Rep 518

Attica Sea Carriers Corp v Ferrostaal Poseidon Bulk Rederei GmbH (The Puerto Buitrago) [1976] 1 Lloyd's Rep 250 (CA)

Automotive Patterns (Precision Equipment) Ltd v A W Plume Ltd (CA 30 October 1996)

Banco de Portugal v Waterlow and Sons Ltd [1932] AC 452 (HL); [1932] All ER 181 (HL)

Bankes v Jarvis [1903] 1 KB 549

Banque Financière de la Cité v Parc (Battersea) Ltd [1999] AC 221 (HL); [1998] 2 WLR 475 (HL); [1998] 1 All ER 737 (HL)

Barque Quilpué Ltd v Brown [1904] 2 KB 264 (CA)

Bournemouth \& Boscombe Athletic FC v Manchester United FC The Times May 221980 (CA).

British Anzani (Felixstowe) Ltd v International Marine Management (UK) Ltd [1980] 1 QB 137; [1979] 3 WLR 451; [1979] 2 All ER 1093

British Westinghouse Electric and Manufacturing Co Ltd v Underground Electric Rlys Co of London Ltd [1912] AC 673 (HL)

Brown v Muller (1872) LR 7 Exch 319

C

Canada Southern Rly Co v Michigan Central Railroad Co (1984) 45 OR (2d) 257 Chapman v Honig [1963] 2 QB 502 (CA); [1963] 3 WLR 19 (CA); [1963] 2 All ER 513 (CA)

Chatenay v The Brazilian Submarine Telegraph Co Ltd [1891] 1 QB 79 (CA) .....

Clark v Marsiglia (1845) 1 Denio 317, (1845) 16 NY Com Law Rep 808

Clea Shipping Corp v Bulk Oil International Ltd (The Alaskan Trader) (No 2) [1984] 1 All ER 129; [1983] Lloyd's Rep 645

Colley v Overseas Exporters [1921] 3 KB 302; (1921) 8 LI L Rep 127

Cort and Gee $v$ The Ambergate, Nottingham and Boston and Eastern Junction Rly Co (1851) 17 QB 127; 117 ER 1229. 
Davis Contractors Ltd v Farnham UDC [1956] AC 696 (HL); [1956] 3 WLR 37 (HL); [1956] 2 All ER 145 (HL)

Davy Offshore Ltd v Emerald Field Contracting Ltd (1991) 27 ConstLR 138; affd [1992] 2 Lloyd's Rep 142 (CA)

Decro-Wall International SA v Practitioners in Marketing Ltd [1971] 1 WLR 361 (CA); [1971] 2 All ER 216 (CA)

Dodd v Churton [1897] 1 QB 562 (CA)

Dunkirk Colliery Co v Lever (1878) 9 ChD 20 (CA)

Empresa Cubana Importada de Alimentos "Alimport" v Iasmos Shipping Co SA (The Good Friend) [1984] 2 Lloyd's Rep 586.

\section{$\mathbf{F}$}

Fechter v Montgomery (1863) 33 Beav 22; 55 ER 274

Finelli v Dee (1968) 67 DLR (2d) 393

\section{G}

Gator Shipping Corp v Trans-Asiatic Oil Ltd SA (The Odenfeld) [1978] 2 Lloy-

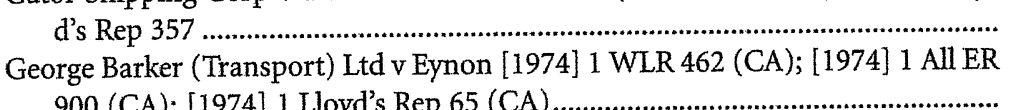
900 (CA); [1974] 1 Lloyd's Rep 65 (CA)

George Trollope \& Sons v Martyn Bros [1934] 2 KB 436 (CA) ...........................

Gilbert Ash (Northern) Ltd v Modern Engineering (Bristol) Ltd [1974] AC 689 (HL); [1973] 3 WLR 421 (HL); [1973] 3 All ER 195 (HL)

\section{H}

Hamlyn \& Co v Wood \& Co [1891] 2 QB 488 (CA)

Hamson (A) \& Son (London) Ltd v S Martin Johnson \& Co Ltd [1953] 1 Lloyd's Rep 553.

Hanak v Green [1958] 2 QB 9 (CA); [1958] 2 WLR 755 (CA); [1958] 2 All ER 141 (CA)

Harrison v Walker [1919] $2 \mathrm{~KB} 453$

Herbert Clayton \& Jack Waller Ltd v Oliver [1930] AC 209 (HL); [1930] All ER 414 (HL)

Heyman and anor v Darwins Ltd [1942] AC 356 (HL); [1942] 1 All ER 337 (HL)

Hickman \& Co v Roberts [1913] AC 229 (HL)

Hill v CA Parsons \& Co Ltd [1972] 1 Ch 305 (CA); [1971] 3 WLR 995 (CA); [1971] 3 All ER 1345 (CA)

Hochster v De La Tour (1853) 2 E\&B 678; 118 ER 922

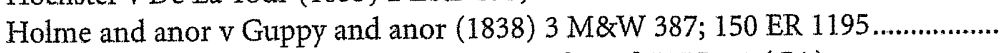

Hopkins v Norcros Plc [1993] ICR 11 (CA); [1994] IRLR 18 (CA). 
Hounslow London BC v Twickenham Gardens Developments Ltd [1971] Ch 233; [1970] 3 WLR 538; [1970] 3 All ER 326

Howard v Pickford Tool Co Ltd [1951] KB 417 (CA).

Hunt (J) v Bishop (1853) 8 Exch 675; 155 ER 1523

Hyde and Schneider v United States 225 US 347; 32 S Ct 793 (1911)

14,44

17

12

I

Inchbald v Western Neilgherry Coffee, etc, Co (1864) 17 CB (NS) 733

Interfoto Picture Library Ltd v Stiletto Visual Programmes Ltd [1989] QB 433

(CA); [1988] 2 WLR 615 (CA); [1988] 1 All ER 348 (CA)

$17,36,61$

18

J

Jamal (AKAS) v Moolla Dawood, Sons \& Co [1916] 1 AC 175 (PC)

Jebco Properties Ltd v Mastforce Ltd [1992] NPC 42

Jones v St John's College, Oxford (1870) LR 6 QB 115

Jones v Swansea CC [1990] 1 WLR 54 (CA); [1990] 3 All ER 162 (CA); reversed: [1990] 1 WLR 1453 (HL); [1990] 3 All ER 737 (HL)

$\mathrm{K}$

Kleinert v Abosso Gold Mining Co (1913) 58 SJ 45 (PC)

Koch Marine Inc v D'Amica Societá Di Navigazione ARL (The Elena D'Amico) [1980] 1 Lloyd's Rep 75

Kurt A Becher GmbH \& Co KG v Roplak Enterprises SA (The World Navigator) [1991] 2 Lloyd's Rep 23

\section{$\mathbf{L}$}

Langford \& Co Ltd v Dutch 1952 SLT 72; 1952 SC 15

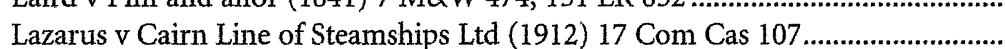
Lister v Romford Ice and Cold Storage Co Ltd [1957] AC 555 (HL); [1957] 2 WLR 158 (HL); [1957] 1 All ER 125 (HL); [1956] 2 Lloyd's Rep 505 (HL) ... Little v Courage Ltd (1995) 70 P\&CR 469.

Liverpool City Council v Irwin and anor [1976] QB 319 (CA); [1975] 3 WLR 663 (CA); [1975] 3 All ER 658 (CA); affd in [1977] AC 239 (HL); [1976] 2 WLR 562 (HL); [1976] 2 All ER 39 (HL)

Luxor (Eastbourne) Ltd v Cooper [1941] AC 108 (HL) $19,20,22$ $17,18,24,37$

\section{$\mathbf{M}$}

Macintosh v The Midland Counties Rly Co (1845) 14 M\&W 548; 153 ER 592....

Mackay v Dick (1881) 6 App Cas 251 (HL)

27

$12,17,25,26,35$

Marbé v George Edwardes (Daly's Theatre) Ltd [1928] 1 KB 269 (CA) .................

Marks v Lilley [1959] 1 WLR 749; [1959] 2 All ER 647 ......................................... .

Merton London BC v Stanley Hugh Leach Ltd (1985) 32 BuildLR 51.................. 


\section{MARGARIDA LiMA REGO}

Metro Meat Ltd v Fares Rural Co Pty Ltd [1985] 2 Lloyd's Rep 13 (PC).......

Mona Oil Equipment \& Supply Co Ltd v Rhodesia Railways Ltd [1949] 2 All

ER 1014; (1949) 83 Ll L Rep 178

17,25

Moorcock, The (1889) 14 PD 64 (CA)

17,22

Morris v Lutterel (1599) Cro Eliz 672; 78 ER 910.

16

Mosvolds Rederi A/S v Food Corp of India (The Damodar General T J Park and King Theras) [1986] 2 Lloyd's Rep 68.

$\mathrm{N}$

Nelson v Dahl (1879) 12 ChD 568 (CA); affd (1881) 6 App Cas 38 (HL)...... Nissho Iwai Petroleum Inc v Cargill International SA [1993] 1 Lloyd's Rep 80 North Sea Energy Holdings NV v Petroleum Authority of Thailand [1997] 2 Lloyd's Rep 418; [1999] 1 Lloyd's Rep 483 (CA)

O

Ogdens Ltd v Nelson [1905] AC 109 (HL)

$\mathbf{P}$

Panameña Europea Navegación Cia Lda v Frederick Leyland \& Co Ltd [1947] AC 428 (HL)

Photo Production Ltd v Securicor Transport Ltd [1980] AC 827 (HL); [1980] 2 WLR 283 (HL); [1980] 1 All ER 556 (HL)

Planché v Colburn (1831) 8 Bing 14; 131 ER 305; [1924-34] All ER Rep $94 .$.

Pound (AV) \& Co Ltd v MW Hardy \& Co Inc [1956] AC 588 (HL); [1956] 2 WLR 683 (HL); [1956] 1 All ER 639 (HL); [1956] 1 Lloyd's Rep 255 (HL)

Prenn v Simmonds [1971] 1 WLR 1381 (HL); [1971] 3 All ER 237 (HL)......

\section{$\mathbf{R}$}

Reardon Smith Line Ltd v Yngvar Hansen-Tangen and Sanko Steamship Co Ltd (The Diana Prosperity) [1976] 1 WLR 989 (HL); [1976] 3 All ER 570 (HL); [1976] 2 Lloyd's Rep 621 (HL).

Rhodes v Forwood (1876) 1 App Cas 256

Roberts v Bury Improvement Commissioners (1870) LR 5 CP 310................

Rockingham County v Luten Bridge Co (1929) 35 F 2d 301.

7,27

Russell v Sá da Bandeira (1862) 13 CB(NS) 149

S

Scally v Southern Health \& Social Services Board [1992] 1 AC 294 (HL); [1991] 3 WLR 778 (HL); [1991] 4 All ER 563 (HL)

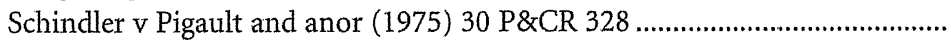

Sealace Shipping Co Ltd v Oceanvoice Ltd (The Alecos M) [1991] 1 Lloyd's Rep 120 (CA) 
NO RIGHT TO PERFORM A CONTRACT?

Secretary of State for Employment v Associated Society of Locomotive Engineers and Fireman and ors (No 2) [1972] 2 QB 455 (CA); [1972] 2 WLR 1370

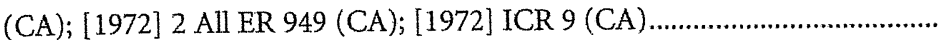
Shell UK Ltd v Lostock Garage Ltd [1976] 1 WLR 1187 (CA); [1977] 1 All ER 481 (CA)

Shindler v Northern Raincoat Co Ltd [1960] 1 WLR 1038; [1960] 2 All ER 239. Shirlaw v Southern Foundries (1926) Ltd and Federated Foundries Ltd [1939] 2 KB 206 (CA); [1939] 2 All ER 113 (CA)

Sociedad Financiera de Bienes Raíces SA v Agrimpex Hungarian Company for Agricultural Products (The Aello) [1961] AC 135 (HL); [1960] 3 WLR 145 (HL); [1960] 2 All ER 578 (HL); [1960] 1 Lloyd's Rep 623 (HL)

Sotiros Shipping Inc and Aeco Maritime SA v Sameiet Solholt (The Solholt) [1983] 1 Lloyd's Rep 605 (CA)

South Australia Asset Management Corp v York Montague Ltd [1997] AC 191 (HL); [1996] 3 WLR 87 (HL); [1996] 3 All ER 365 (HL)

Southern Foundries (1926) Ltd and Federated Foundries Ltd v Shirlaw [1940] AC 701 (HL); [1940] 2 All ER 445 (HL)

Sprague v Booth [1909] AC 576 (PC)

Stirling v Maitland (1864) 5 B\&S 840

Stocznia Gdanska SA v Latvian Shipping Co [1996] 2 Lloyd's Rep 132 (CA) ....... Sunbeam Shipping Co Ltd v President of India (The Atlantic Sunbeam) [1973] 1 Lloyd's Rep 482

Thompson v Asda-MFI Group plc [1988] Ch 241; [1988] 2 WLR 1093; [1988] 2 All ER 722

Tredegar Iron \& Coal Co Ltd v Hawthorn Bros \& Co (1902) 18 TLR 716 (CA)... 16, 47, 49, 61 Trollope \& Colls Ltd v North West Metropolitan Regional Hospital Board [1973] 1 WLR 601 (HL); [1973] 2 All ER 260 (HL)

U

Unique Mariner (No 2) [(The) 1979] 1 Lloyd's Rep 37

\section{W}

Walford v Miles [1992] 2 AC 128 (HL); [1992] 2 WLR 174 (HL); [1992] 1 All ER 453 (HL).

Westwood v Secretary of State for India (1863) 7 LT 736

White \& Carter (Councils) Ltd v McGregor [1962] AC 413 (HL); [1962] 2 WLR 17 (HL); [1961] 3 All ER 1178 (HL)

William Cory \& Son Ltd v City of London Corp [1951] 2 KB 476 (CA); [1951] 2 All ER 85 (CA); [1951] 1 Lloyd's Rep 475 (CA). 
Margarida lima Rego

Preliminary CHAPTER

\author{
I know who I was when I got up this morning, \\ but I think I must have changed several times since then. ${ }^{1}$
}

People are often poor at predicting changes, both in external circumstances and in their own personal preferences. Hence they must frequently come to the conclusion that some of their past decisions have become obsolete. This dissertation is about regret. More specifically, it is concerned with cases where one contracting party loses all interest in the other party's performance after a contract has been entered into but before it has been acted upon. I am particularly concerned with the contract for the supply of services (in a fairly broad sense) ${ }^{2}$, and within that type of contract I shall focus on the situation where the abdicating party is the service recipient $(R)$, rather than its provider (P). I shall confine myself entirely to the case of the discrete commercial contract where the parties deal at arm's length and are in need of no special protection.

The origins of my interest in this topic lie in a general dissatisfaction with the controversial decision of the House of Lords in White \& Carter (Councils) $v M c G r e g o r^{3}$. Contrary to the vast majority of its detractors, however, the focus of my dissatisfaction is not so much the sheer waste of resources that it leads to but rather the utter powerlessness of the defendant to prevent the other party from performing his part of the contract. 'Surely the conclusive question is not whether the performance is unwanted, but whether it is worthless', so the argument goes. I beg to differ. In this dissertation I shall look into the legal position of a party $(R)$ who has lost all interest in the services he has contracted for, with a view to support the recognition of his right to reject and even prevent the unwanted supply of services.

It is not my intention to question the binding force of wholly executory contracts. Nor do I propose to promote the recognition of a power to unilaterally rescind the contract (aside from cases of major breach), if only because

1 Alice's reply to the Caterpillar. L Carroll Alice's Adventures in Wonderland in RL Green (ed) The Works of Lewis Carroll (Spring Books London 1965) 50. Quoted in EA Farnsworth Changing your Mind: the Law of Regretted Decisions (YaleUP London New Haven 1998) 26.

2 So, for instance, I would include in my notion of supply of services a contract for work and materials but not a straightforward sale of goods.

3 [1962] AC 413 (HL).

4 PM Nienaber 'The effect of anticipatory repudiation: principle and policy' [1962] CLJ 213, 233. 
any such recognition would dangerously undermine the entire institution of contract as we know it. Quite on the contrary, the line of argument that I intend to pursue is grounded on the perception that it is conceptually viable to hold that $R$ may lawfully prevent $P$ from performing his part of the contract whilst keeping the contract alive.

I shall begin my analysis of this problem by looking into the reasons why prevention of another party's performance - whether active or by omission is at present almost universally characterised as a breach of contract. At the heart of this approach seems to be the suggestion, sometimes made, that the common law imposes on the parties to a contract a duty to cooperate in order to facilitate the fulfilment of their bargain. ${ }^{5}$ Indeed, cooperation is by definition the antithesis of prevention. Hence in Chapter One I shall be looking into the origins of this so-called duty to cooperate and to the process by which the courts have come to imply it in order to discern where things might have gone astray.

When faced with the situation under analysis, the courts tend to favour performance for the sake of performance alone, never pausing to ask exactly whose contractual interest is at stake in each particular factual situation. By focusing on 'the bargain', rather than the parties' mutual promises, the dutybased approach to cooperation takes for granted that each party has an unfettered right to perform his own part of the contract free from interference, overlooking the possibility that such a right might in fact not have been intended at all by the parties themselves. This attitude grants the contract a sort of autonomous life of its own, in that the parties are treated as if they were bound to fulfil 'it', rather than each other's reasonable expectations.

My objective at this stage is to take a purposive approach to contractual interpretation and concentrate on the parties' reasonable expectations as to the outcome of the contractual undertaking. Although references in legal writings to the spirit of 'the deal', the common purpose of 'the transaction' or the duty to facilitate fulfilment of 'the bargain' are exceedingly common, the fact

5 See F Pollock Principles of Contract (9th edn Stevens \& Sons London 1921) 294; EW Patterson 'Constructive conditions in contracts' (1942) 42 CollRev 903; SJ Stoljar 'Prevention and cooperation in the law of contract' (1953) 31 CanBarRev 231; AJ Bateson 'The duty to cooperate' [1960] JBL 187; JF Burrows 'Contractual cooperation and the implied term' (1968) 31 MLR 390; H Collins The Law of Contract (3rd edn Butterworths London 1997) Ch 15; JM Paterson 'Terms implied in fact: the basis for implication' (1998) 13 JCL 103; HG Beale (ed) Chitty on Contracts (28th edn Sweet \& Maxwell London 1999) $\$ \$ 13-011$ and 13-012; AF Mason 'Contract, good faith and equitable standards in fair dealing' [2000] 116 LQR 66; E Peden "Cooperation" in English contract law - to construe or imply?' (2000) 16 JCL 56. 
remains that the typical executory contract - if there is such a thing as a typical executory contract - is an exchange of promises, each made for the sole benefit of its promisee. Each party to the contract will have purchased, with his own promise, a right to demand performance of the counter-promise nothing more, nothing less. A purposive approach to construction, whilst potentially requiring a certain degree of cooperation to take place during performance of the contract, will clearly not promote a vision of contract as a cooperative venture, to the exclusion of a party's individual best interest.

Bearing this in mind, I shall attempt to explain how the traditional promissory approach to cooperation originated in an improper overgeneralization of authority that gave rise to an unsuitably framed rule of construction. ${ }^{6}$ I shall analyse leading cases such as Mackay $v$ Dick, ${ }^{7}$ where the courts felt compelled to imply a duty to cooperate even though the outcome of those cases could ultimately have been reached by a different and more suitable rationale. I hope to demonstrate that such implication was neither necessary nor reasonable.

The central aim of this chapter is therefore to put forward that, whereas each contractual party has a duty to cooperate so as not to frustrate the other party's legitimate expectations, when it comes to his own legitimate expectations that party is merely faced with a choice between two alternative courses of action, both of which are lawful: either to cooperate and fulfil these expectations, or not to cooperate and suffer the consequences of his own lack of cooperation. Thus, I conclude this chapter by contending that the concept of a 'burden', rather than that of a duty, better encapsulates the true meaning of the requirement of cooperation as to the latter type of expectations.

Having thus paved the way for the submission that there are other ways of taking a contractual risk beyond the making of a promise, I shall begin Chapter Two by tackling the issue of contractual risk-allocation itself, concentrating on those instances of risk bearing that go beyond the scope of the contractual promises, that is, on those situations where loss was sustained even though no breach was committed and no liability arose. My main intention in this chapter is, however, to explore the possibility of finding an alternative conceptual framework for the requirement of cooperation in its characterisation as a contingent condition subsequent to P's duty to perform.

6 'It is one of the misfortunes of the law that ideas become encysted in phrases and thereafter for a long time cease to provoke further analysis.' Hyde and Schneider $v$ United States (1911) 225 US 347 (Mr Justice Holmes) 391.

7 (1881) 6 App Cas 251 (HL). 
NO RIGHT TO PERFORM A CONTRACT?

Indeed, it seems perfectly plausible that someone should wish to secure a contractual right to a given service, without at the same time promising that he will accept it when it becomes due. I shall submit that, even though $\mathrm{R}$ must generally bear the risk of losing interest in the services he has contracted for, it does not inexorably follow that he must endure them, inasmuch as his obligations towards $\mathrm{P}$ do not go beyond assuring that his legitimate contractual expectations are adequately met. By way of illustration, when $\mathrm{R}$ buys a cinema ticket he normally does not intend to bind himself to turn up at the right time and sit attentively through the whole film. He is satisfied that he will have fulfilled all his contractual obligations by paying the price and should he decide to turn up - not littering the theatre nor being a nuisance to the others present.

I must deal with P's alleged right to earn the full contract price, for this appears to be the main obstacle to the recognition of R's right to prevent $P$ from performing. Indeed, as long as one sustains the view that by preventing $\mathrm{P}$ from performing $\mathrm{R}$ will also be preventing him from earning the right to the full contract price, there is no way of contending that $\mathrm{R}$ should be recognised such a power, for its exercise would automatically injure P's legitimate contractual expectations. Therefore I shall try to do away with this conception and also reject the proposition that a promisor has an unfettered right to perform his promise. I shall argue that such right should be recognised only where it was (explicitly or more commonly implicitly) bargained for at the time of contracting.

When construing a contract one must start by enquiring what exactly each party has bargained for, and the exact scope of the rights and duties which they have agreed. In the situation under analysis, two alternative end results seem equally plausible: either (a) R's cooperation is mandatory, in which case P's right to the contract price can be made conditional upon his agreed supply of services; or (b) it is discretionary, in which case P's right to the contract price cannot depend on the actual rendering of his services to $R$. The traditional approach to construction is flawed by a form of dogmatic reasoning, in that it takes for granted that P's right to the full contract price is always conditional upon his actual supply of services, thereby failing to recognise the need for such an enquiry, since only (a) matches such an assumption.

The main purpose of this chapter is therefore to show that, whilst it can be said that P's right to the full contract price is conditional upon due performance of his part of the contract, it does not necessarily follow that it is conditional upon the actual rendering of his services to $\mathrm{R}$, insofar as, should $R$ release $P$ from such a duty, $R$ will still be prima facie liable for the full contract price. 
Whereas from P's standpoint it may be enough to regard his own supply of services as conditional upon R's cooperation, what the latter really needs is recognition of his right to renounce P's performance. Indeed, such recognition is absolutely essential if we are to extend this solution to cases where no cooperation is needed for $\mathrm{P}$ to perform his part of the contract. Therefore, I shall proceed in Chapter Three to advocate the recognition of a general right to renounce one's own contractual rights as long as one has performed or is willing to perform one's own duties under the contract.

I shall begin this chapter by going through the doctrine of anticipatory breach of contract in order to make clear why it is inapplicable to the problem under scrutiny. It is my submission that one should look at prevention without automatically characterising it as a breach of contract in the shape of a repudiation, and that even in the presence of an unambiguous repudiation (which, if unaccepted, should be 'a thing writ in water's), insofar as the contract remains in force, the subject of R's entitlement to reject and prevent P's performance should be dealt with as something entirely separate from that of the futility of his attempted termination.

Hence the question that should be asked is, once again, whether in each particular factual situation $\mathrm{P}$ has bargained for the right to perform his part of the contract, and only when he has should one ask whether it has been improperly exercised. If he has not, however, it is my submission that $\mathrm{R}$ should be recognised the right to reject and even prevent $P$ from performing. I shall contend that all $\mathrm{R}$ must do is let $\mathrm{P}$ know that he no longer has an interest in his performance, and performance of that particular promise ceases to be legally possible, because whichever course of action $\mathrm{P}$ decides to take his conduct will no longer be susceptible of being characterised as that promise's performance. I shall call this purely conceptual remedy 'prevention by notification'. Should P decide to 'perform' against R's will he will be doing so at his own risk, and may even be held liable for whatever harm the latter may come to suffer as a consequence of his conduct. Depending on the consequences of such conduct, P's insistence on 'performance' after R's renunciation might properly be characterised as a breach of contract or even as a breach of a duty of care towards $\mathrm{R}$.

In Chapter Four I shall explore the possibility of allowing $\mathrm{R}$ to set off against his payment of the full contract price any expense that $P$ might have saved and any profit that he might have made as a result of his release from the obligation to supply his services. At the outset this amounts to an application of the doctrine of mitigation in fact, since the question here is not

8 Howard v Pickford Tool Co [1951] KB 417 (CA) 421 (Asquith LJ). 
NO RIGHT TO PERFORM A CONTRACT?

whether $\mathrm{P}$ is 'bound' to mitigate his loss but whether his loss was in fact mitigated due to his early discharge. I shall discuss the reasons why the doctrine of mitigation should apply to this case even though $\mathrm{P}$ is prima facie asking for the full contract price rather than for an award of damages for breach of contract.

Essentially, I shall submit that in this case there is an element of compensation in P's remedy, given that the award of the contract price is aimed at putting him in the position he would have been in had he duly supplied his services to $R$, rather than at rewarding him for the actual performance of those services. Therefore, the expectation measure becomes relevant, and so does the concept of loss (or the lack thereof). Conversely, whenever such savings do not occur due to P's insisting 'performance', the question is primarily one of characterisation: whatever he failed to save must not be taken into account it must not be characterised as constituting an expense in any way related to performance of his contractual obligations. He shall have to bear that loss himself. In addition, whenever his conduct in attempting to 'perform' is unlawful, he shall have to compensate $\mathrm{R}$ for any loss his 'performance' might have caused him.

\section{CHAPTER I}

THE PROMISSORY APPROACH TO COOPERATION

\section{A. A DUTY TO COOPERATE?}

It is often said that the law of contract's main purpose is to create an environment where individuals are able and encouraged to maximise their own utilities through the means of cooperation. The word 'cooperation' is being used here in its strictest possible sense, meaning necessary coordination in the pursuit of self-interest. In most transactions, it would appear that such cooperation simply requires performance to take place according to what was expressly agreed by the parties. And that will happen largely as a result of the economic or other self-interest that led them into entering the transaction in the first place. Hence a shopkeeper will hand over the goods in exchange for payment by the customer; and a mechanic will fix the client's car, being paid in return for this service once it has been completed.

English contract law traditionally limited its intervention to upholding express agreements and setting the conditions under which one party might 
terminate a contract in the face of a breach by the other. ${ }^{9}$ This traditional approach to contract law - which today still exerts a considerable amount of influence amongst both practitioners and academics - is firmly grounded on an antagonistic conception of the business of contracting. Underlying it is an adversarial model where each contracting party seeks to maximise its utility in the context of tough negotiation, and where the resulting contract is regarded as a combination of their fundamentally opposing selfish interests. In its purity, this approach essentially postulates that the contract must be performed in accordance with what has been strictly agreed upon at the time of contracting and that beyond that the parties need not worry about each other's best interest. Imposition of additional duties of cooperation not only appeared unnecessary but also threatened to breach the principle that the parties must consent to all contractual obligations.

Eventually, it became apparent that such an insular approach to construction was grossly inadequate, and could be the source of great injustice. ${ }^{10}$ For no matter what the particular circumstances of a case may be, there are usually ways of evading the spirit of a deal whilst externally following the express terms of the contract to the very letter. ${ }^{11}$ Towards the mid 19th century, the courts slowly began to adhere to the idea that the parties to a contract might be under an obligation not to hinder each other from performing their part of the contract. ${ }^{12}$ Or that where a contract was made subject to a condition pre-

9 See H Collins The Law of Contract (3rd edn Butterworths London 1997) Ch 15.

10 For instance, in Morris v Lutterel (1599) Cro Eliz 672; 78 ER 910, an early action on a penal bond conditioned for the payment of $£ 100$ on a certain day, the fact that the claimant covinously caused the defendant to be imprisoned while he was on his way to make the payment did not forfeit his duty to pay the penalty. See, however, SJ Stoljar 'Prevention and co-operation in the law of contract' (1953) 31 CanBarRev 231, 234, where the author puts forward his differing views on the correct interpretation of this and other similar early cases.

11 See Secretary of State for Employment $v$ Associated Society of Locomotive Engineers and Fireman (No 2) [1972] 2 QB 455 (CA) for an enlightened reaction to the 'work to rule' situation in the context of an employment contract.

12 'There is an implied contract by each party that he will not do anything to prevent the other party from performing the contract or to delay him in performing it. I agree that generally such a term is by law imported into every contract.' Barque Quilpué Ltd v Brown [1904] 2 KB 264 (CA) 271. See also Stirling v Maitland (1864) 5 B\&S 840, 852; Rhodes $v$ Forwood (1876) 1 App Cas 256 (HL) 272, 274; Turner $v$ Goldsmith [1891] 1 QB 544 (CA); Ogdens Ltd v Nelson [1905] AC 109 (HL); Southern Foundries v Shirlaw [1940] AC 701 (HL); William Cory \& Son Ltd $v$ City of London Corp [1951] 2 KB 476 (CA) 484; Hamson \& Son $v$ S Martin Johnson \& Co [1953] 1 Lloyd's Rep 553; Shindler v Northern Raincoat Ltd [1960] 1 WLR 1038; The Unique Mariner (No 2) [1979] 1 Lloyd's Rep 37; Tredegar Iron \& Coal Co v Hawthorn Bros \& Co (1902) 18 TLR 716 (CA). 
cedent - apparently whether promissory or merely contingent - it might be their duty to do nothing to hinder its fulfilment. ${ }^{13}$ Such is the so-called negative side of the duty to cooperate. Eventually, they also came to recognise the existence of a contractual duty to cooperate actively in order to help the other party perform his part of the contract, where such cooperation was necessary to complete it. Thus Lord Blackburn, in Mackay v Dick ${ }^{14}$, stated that

where in a written contract it appears that both parties have agreed that something shall be done, which cannot effectually be done unless both concur in doing it, the construction of the contract is that each agrees to do all that is necessary to be done on his part for the carrying out of that thing, though there may be no express words to that effect. ${ }^{15}$

From that moment onwards, the courts have persistently (if not always consistently) adopted Lord Blackburn's dictum, treating this as a matter of construction: a duty to cooperate, being generally not expressly provided for, would usually be implied where it was 'necessary to give business efficacy to the contract' 16 , that is, where it was called for by the commercial purpose of the transaction. ${ }^{17}$ This technique allowed the courts to contend that both the

13 See Inchbald $v$ Western Neilgherry Coffee, etc, Co (1864) 17 CB (NS) 733, 741; Roberts v Bury Improvements Commissioners (1870) LR 5 CP 310, 316, 325; Mackay v Dick (1881) 6 App Cas 251 (HL); Hickman \& Co v Roberts [1913] AC 229 (HL); George Trollope \& Sons v Martyn Bros [1934] 2 KB 436 (CA); Bournemouth \& Boscombe Athletic FC v Manchester United FC The Times May 221980 (CA); Jebco Properties v Mastforce Ltd [1992] NPC 42.

14 (1881) 6 App Cas 251 (HL). Note that this was an appeal from a Scottish case.

15 Same case 263. See also Hunt v Bishop (1853) 8 Exch 675; 155 ER 1523; Roberts v Bury Improvements Commissioners (1870) LR 5 CP 310, 316, 325; Nelson v Dahl (1879) 12 ChD 568 (CA) 592; affd (1881) 6 AC 38 (HL).

16 See Bowen LJ's definition of the 'business efficacy' test in The Moorcock (1889) 14 PD 64 (CA) 68 and also MacKinnon LJ's definition of the alternative 'officious bystander' test in Shirlaw $v$ Southern Foundries [1939] 2 KB 206 (CA) 227.

17 See Sprague v Booth [1909] AC 576 (PC) 580; Kleinert v Abosso Gold Mining Co (1913) 58 SJ (PC) 45; Harrison v Walker [1919] 2 KB 453; Colley v Overseas Exporters [1921] 3 KB 302, 309; Panameña Europea Navegación v Frederick Leyland \& Co [1947] AC 428 (HL) 436; Luxor (Eastbourne) Ltd v Cooper [1941] AC 108 (HL) 118; Mona Oil Equipment v Rhodesia Railways Ltd [1949] 2 All ER 1014, 1017-8; Pound (AV) \& Cov MW Hardy \& Co [1956] AC 588 (HL) 608, 611; Sociedad Financiera de Bienes Raices v Agrimpex (The Aello) [1961] AC 135 (HL) 186, 220; Sunbeam Shipping Co v President of India [1973] 1 Lloyd's Rep 482, 486; Schindler v Pigault (1975) 30 P\&CR 328; Metro Meat Ltd v Fares Rural Co Pty [1985] 2 Lloyd's Rep 13 (PC) 14; Merton London BC v Stanley Hugh Leach (1985) 32 BuildLR 51; Thompson v Asda-MFI Group plc [1988] Ch 241, 266; Kurt A Becher v Roplak Enterprises SA (The World Navigator) 
existence, in any given case, of an actual duty to cooperate and the degree of cooperation required were to be determined, not by what seemed reasonable, but by what they perceived to be the unexpressed intention of the parties to the contract - which meant that the principle of consent remained formally unchallenged.

The courts have repeatedly felt the need to adopt a more purposive approach to construction. The common law being averse to broad overriding principles such as that of good faith but favouring the adoption of piecemeal solutions in response to demonstrated problems of unfairness ${ }^{18}$, they have accomplished it by resorting to the technical device of the implied term - where cooperation is necessary, it is implied that it will be forthcoming. This general rule of construction is ultimately an abstraction that requires tailoring to the facts of the particular factual situation and the needs of the particular parties in order to acquire any specific content, giving rise to individual and concrete duties to cooperate. When determining their scope the courts hide behind a façade: that of the parties' unexpressed intention. They do this through the requirement of necessity.

The reasoning followed is fairly simple, and seemingly flawless: surely the parties to a contract must have wanted it to be fully and efficiently performed, so they must have intended to cooperate whenever such cooperation is essential to the full realisation of their bargain. Where cooperation is necessary, it is implied that it will be forthcoming. ${ }^{19}$ In other words, if the parties want $x$ to take place and in order for that to happen $y$ must take place too, it is implied that it is their duty to make $y$ happen as well. Thus - so the story goes - a man who engages an artist to paint his portrait implicitly promises that he will give the necessary sittings.

\section{B. Protecting the Parties’ REASONABLe eXPeCtations}

During the 20th century, this somewhat restrictive view was challenged by occasional suggestions that the courts should imply terms as long as they were

[1991] 2 Lloyd's Rep 23, 30, 34; Davy Offshore v Emerald Field Contracting (1991) 27 ConstLR 138 (CA); Nissho Iwai Petroleum v Cargill International SA [1993] 1 Lloyd's Rep 80, 84; Automotive Patterns (Precision Equipment) Ltd v A W Plume Ltd (CA 30 October 1996); North Sea Energy Holdings v Petroleum Authority of Thailand [1999] 1 Lloyd's Rep 483 (CA) 492.

18 See Interfoto Picture Library v Stiletto Visual Programmes [1989] QB 433 (CA) 439 (Bingham LJ).

19 Luxor (Eastbourne) Ltd v Cooper [1941] AC 108 (HL) 118 (Viscount Simon LC). 
reasonable. ${ }^{20}$ And in certain specific types of contract some implied terms have since become standardised, and will now be implied in all contracts of that type in the absence of any contrary intention. These terms are often said to be implied in law, as opposed to the former which are implied in fact. ${ }^{21}$ Thus terms are frequently implied into contracts of employment and tenancies, not on the basis of the circumstances of the particular parties, but as a general incidence of the relationship of employer and employee or landlord and tenant.

This process of decision is quite independent of the intention of the parties except that they are normally free, by using express words, to exclude the terms which would otherwise be implied. Consequently - as the House of Lords has recently acknowledged - a distinction should be drawn 'between the search for an implied term necessary to give business efficacy to a particular contract and the search, based on wider considerations, for a term which the law will imply as a necessary incident of a definable category of contractual relationship.'22

This somewhat broader power to imply terms is said to be confined in two ways: firstly, the transaction has to fall within one of the recognised standard types of contract; secondly, its use will be limited to terms which would generally be applicable to the relevant standard type of contract. ${ }^{23}$ As a result, whilst such wider considerations have allowed courts to impose certain duties of cooperation in the context of tenancies or employment contracts, this recent development of the law would appear, on the surface, not to have had a tremendous impact on the general attitude of the law

20 See Lord Denning MR's judgments in Liverpool City Council v Irwin [1976] QB 319 (CA) and in Shell UK v Lostock Garage [1976] 1 WLR 1187 (CA).

21 See GH Treitel The Law of Contract (10th edn Sweet \& Maxwell London 1999) 183-95; JF Burrows 'Contractual co-operation and the implied term' (1968) 31 MLR 390 and 'Implied terms and presumptions' (1968) NZULRev 121; ABL Phang 'Implied terms revisited' [1990] JBL 394, 'Implied terms in English law - some recent developments' [1993] JBL 242 and 'Implied terms again' [1994] JBL 255; JW Carter and GJ Tolhurst 'The new law on implied terms' (1996) 11 JCL 76 and 'Implied terms: refining the law' (1997) 12 JCL 152; JM Paterson 'Terms implied in fact: the basis for implication' (1998) 13 JCL 103.

22 Scally $v$ Southern Health \& Social Services Board [1992] 1 AC 294 (HL) 307 (Lord Bridge). His Lordship grounded this statement on two earlier decisions of the House of Lords: Lister $v$ Romford Ice and Cold Storage Co [1957] AC 555 and Liverpool City Council v Irwin [1977] AC 239. For the distinction between the two processes, see also Mosvolds Rederi A/S v Food Corp of India [1986] 2 Lloyd's Rep 68, 70-71 and Ali Shipping Corp v Shipyard Trogir [1998] 2 All ER 136 (CA) 146-147.

${ }^{23} \mathrm{H}$ Collins The Law of Contract (3rd edn Butterworths London 1997) 225-226. 


\section{MARgaRida Lima Rego}

of contract towards the requirement of cooperation in the context of commercial transactions.

One cannot however be so naïve as to believe that there is such a clear-cut distinction between terms implied in fact and terms implied in law. This is partly due to the fact that there has always been a certain ambiguity in the way that the courts treat the concept of presumed intent. For construing a contractual term based on what the parties probably would have intended is not the same as giving effect to what the parties actually did intend.

An implied term based on the parties' presumed actual intentions would be an attempt to express the intentions the parties probably actually held but did not bother to express. An implied term based on the parties' hypothetical intentions would be an attempt to approximate the term the parties would probably have agreed if they had considered the issue in dispute when making their contract. Judicial views are not entirely settled, or consistent, on which of these two meanings of presumed intent should govern. ${ }^{24}$

According to Glanville Williams, referring to these two kinds of implication and to the implication of terms in law, 'although the line between the three cases can be made sharp as a matter of definition, in practice they merge imperceptibly into each other, because the distinguishing factor, that of probable intent, is a matter of degree.'25 Indeed, in the words of JF Burrows, ' $[t]$ he "implied term" area is best viewed as a descending scale, rather than as divided into two, or even three "classes"'26

So whilst what the courts have been saying is that outside those terms which have now become standardised it is the parties alone who can impose a duty to cooperate, and that consequently it is their duty to scrutinise each case closely for indications of their intention, such statements cannot be taken at face value. It is difficult enough to discover the actual intention of an individual, let alone the common intention of the parties to a contract, on a matter that they probably never even considered. 'The fact that a term seems necessary or obvious once a dispute has arisen does not mean that the term was actually intended by the parties at the time the contract was

${ }^{24}$ JM Paterson 'Terms implied in fact: the basis for implication' (1998) 13 JCL 103, 107.

25 GL Williams 'Language and the law - IV' [1945] 61 LQR 384, 401.

26 JF Burrows 'Implied terms and presumptions' (1968) NZULRev 121, 140 n 85. See Lord Wilberforce's reference to 'a continuous spectrum' in Liverpool CC $v$ Irwin [1977] AC 239 (HL) 254. 


\section{NO RIGHT TO PERFORM A CONTRACT?}

made, although it may be a good approximation of the parties' hypothetical intentions.'27

At the end of the day, it is the courts that are imposing their own views of what the parties ought to have intended, which is why their outward deference to the parties' intentions has been criticised by a number of commentators as well as quite a few judges - as a misleading fiction. Thus, almost fifty years ago - albeit in the special context of the law of frustration - Lord Radcliffe declared that

[b]y this time it might seem that the parties themselves have become so far disembodied spirits that their actual persons should be allowed to rest in peace. In their place there arises the figure of the fair and reasonable man. And the spokesperson of the fair and reasonable man, who represents after all no more than the anthropomorphic conception of justice, is and must be the court itself. ${ }^{28}$

Indeed, the justification for implied terms rests ultimately not on the intentions of the parties themselves but rather on the court's view of what their reasonable expectations are likely to have been ${ }^{29}$, that is, it rests on what the court perceives to be the typical expectations of typical parties to the type of contract under scrutiny. Without them one party would be prevented from obtaining the full value of his expectation under the contract because the other party insists upon limiting his obligations to a strict interpretation of the express terms of the contract. This is why the implication of individual duties to cooperate is above all else a means of protecting the parties' reasonable expectations as to their contract.

\section{Hidden ASSUMptions}

The general rule of construction itself seems unimpeachable: when cooperation is necessary, it is implied that it will be forthcoming. But when is cooperation truly necessary? In the first place, what exactly is meant by the requirement of 'necessity'? To begin with, that requirement clearly does not concern physical necessity, something that calls for a mere inference of causation in fact, rather than a principled evaluation of the fairness or justice of the implication. The problem is definitely not one of 'inevitable infe-

27 JM Paterson 'Terms implied in fact: the basis for implication' (1998) 13 JCL 103, 108.

28 Davis Contractors Ltd v Farnham UDC [1956] AC 696 (HL) 728.

29 See H Collins The Law of Contract (3rd edn Butterworths London 1997) 228. 
rence'. ${ }^{30}$ Hence even though the courts still insist that ' $[\mathrm{t}]$ he touchstone is always necessity and not merely reasonableness ${ }^{3}$, in practice both concepts are inextricably intertwined.

In Liverpool City Council v Irwin ${ }^{32}$, the leading case on the requirement of necessity, the House of Lords held that it was an implied term of a lease of a maisonette in a Council block that the landlord should take reasonable care to keep the common parts of the block in a reasonable state of repair. And yet, in Atiyah's words

[i]t is not necessary to have lifts in blocks of flats ten stories high, though it would no doubt be exceedingly inconvenient not to have them. So necessary really means reasonably necessary, and that must mean reasonably necessary having regard to the context and the price. So in the end there does not seem to be much difference between what is necessary and what is reasonable. ${ }^{33}$

Moreover, when applying the general rule of construction to a case, the courts surreptitiously tie themselves to a number of assumptions, allegedly in the course of ascertaining the parties' unexpressed intention. ${ }^{34}$ The biggest assumption of all stems from their focusing their attention on 'the bargain', rather than the parties' mutual promises. The problem with such an approach is that it takes for granted that both parties will have bargained for one and the same end result, so that each of them must be recognised an unfettered right to perform his own part of the deal free from interference - the negative side of cooperation - and even a right to demand each other's help whenever such help is reasonably necessary in order to accomplish that end result - the positive side of cooperation. In short, the courts start by assuming that both par-

30 See GP Costigan The Performance of Contract: a Summary of Conditions in Contracts and Impossibility of Performance (TH Flood Chicago 1911) 10.

31 Liverpool CC v Irwin [1977] AC 239 (HL) 266 (Lord Edmund-Davies).

32 [1977] AC 239 (HL).

33 PS Atiyah An Introduction to the Law of Contract (5th edn OUP Oxford 1995) 207. For another illustration of this phenomenon see The Moorcock (1889) 14 PD 64 (CA) itself, where the implication was, to a certain extent, based on objective criteria of reasonableness in defining the precise extent of the implication. See GH Treitel The Law of Contract (10th edn Sweet \& Maxwell London 1999) 193-4.

34 See JF Burrows 'Implied terms and presumptions' (1968) NZULRev 121 for an analysis of the implied term technique in terms of initial presumptions and their rebuttal. It is submitted that the author of this article may actually be alluding to the concept of default rules - which by definition involve a favourable allocation of the burden of proof to those who wish to stick to them - rather than that of presumptions. 
NO RIGHT TO PERFORM A CONTRACT?

ties want the exact same end result to materialise, and then they proceed to assume that the parties by their contract have bound themselves to achieve it.

This approach blatantly overlooks the chance that at least in some cases such rights might in fact not have been intended at all by the contractual parties themselves. It grants the contract a sort of autonomous life of its own, in that the parties are treated as if they were bound to fulfil 'it', rather than each other's reasonable expectations. But the classical model of English contract law is that of a bargain, and a bargain postulates an exchange - an exchange of promises, in the case of the bilateral executory contract. A purposive approach to construction therefore postulates that one looks at a contract as what it truly is - an exchange of promises. Each contractual party will have bargained for whatever the other party has promised to do (or abstain from doing). As a result their own individual expectations must necessarily be different from the other party's, and must therefore be treated accordingly.

An example of this sort of misconceived reasoning may be found in the following words: 'The basic criterion of the implied-in-fact condition is that if the promise cannot be performed until the promisee has done something, then that act or omission is a condition of the promisor's duty.'35 So far, so good. 'In other words, the promisee is required to co-operate with the promisor in the performance of his promise. ${ }^{36}$ How come? There is an unwarranted logical leap in this reasoning, inasmuch as from the recognition that the promisor's duty to perform is conditional upon the promisee's active or passive cooperation it does not necessarily follow that the latter has bound himself to cooperate. There are other ways - over and above the making of a promise of bringing about a certain desired action by another person. ${ }^{37}$

In short, the courts' main assumptions are: (a) the parties have an unfettered right to perform their part of the deal free from interference - the negative side of cooperation; (b) the parties are bound to accomplish one and the same end result, so they must also be bound to do whatever it takes to accomplish that end result - the positive side of cooperation. But these assumptions should be openly acknowledged and justified by the courts. The courts should admit they are making them in the first place, rather than hide behind words like 'intention' and 'necessity'. And they should give good reasons for making these assumptions. Why should they start off with the undisputed belief that cooperation is a duty unless otherwise stated?

35 EW Patterson 'Constructive conditions in contract' (1942) 42 CollRev 903, 929.

36 Same article same page, text immediately following.

37 See AL Corbin 'Conditions in the law of contract' (1919) 28 YaleLJ 739, 746. See 38 below. 


\section{MARGARIDA Lima Rego}

The decisions dealing with the estate agent's commission offer a good illustration of the problem under scrutiny. In Luxor (Eastbourne) Ltd v Cooper ${ }^{38}$, the claimant's right to commission was subject to the conclusion of a sale to purchasers introduced by him. He sued for breach of an alleged implied term that the defendants would do nothing to prevent him from earning his commission. He failed.

The owner is offering to the agent a reward if the agent's activity helps to bring about an actual sale, but that is no reason why the owner should not remain free to sell his property through other channels. ... I think, upon the true construction of the express contract in this case, that the agent also takes the risk of the owner not being willing to conclude the bargain with the agent's nominee. ... If it really were the common intention of owner and agent that the owner should be bound in the manner suggested, there would be no difficulty in so providing by an express term of the contract. But in the absence of such an express term, I am unable to regard the suggested implied term as 'necessary'.39

The approach of the House of Lords was unequivocally on implied term lines. However, although the language of necessity was resorted to, and the decision was allegedly based on the particular circumstances of the case, what truly happened was that a term usually implied in law was altered - to its exact opposite, in fact - so that a distinct default rule was henceforth adopted. The decision of the Court of Appeal in George Trollope \& Sons $v$ Martyn Bros ${ }^{40}$ was overruled, and from then on Luxor was applied in every case that concerned an estate agent's commission in order to substantiate the conclusion that no such duty exists.

Through the implication of terms the courts can structure contracts so that they incorporate a fair and practical allocation of risks, a view that may alter over time. In the Luxor case, it did. The fact is that in most cases involving implied terms the law provides a clear prima facie answer to the problem - a default solution - and one of the parties is asking the court to imply a term that goes against this normal answer. There is nothing intrinsically wrong with that. ${ }^{41}$ However, the problem is that in some of those cases rather than

\footnotetext{
38 [1941] AC 108 (HL).

39 Luxor (Eastbourne) Ltd v Cooper [1941] AC 108 (HL) 117-118 (Viscount Simon LC).

40 [1934] $2 \mathrm{~KB} 436$ (CA).

41 In fact, in those cases where there is no initial default rule the officious bystander test usually makes no sense, as in Trollope \& Colls $v$ North West Metropolitan Regional Hospital Board [1973] 1 WLR 601 (HL). In this case, even though both parties accepted that some term should be implied - for the contract, as it stood, was unwork-
} 
a default rule that can easily be overcome by contrary evidence the courts place a very harsh burden on one of the parties: to prevail over unacknowledged and unjustified assumptions that are virtually impossible to rebut, insofar as, to a large extent, they are unconscious. This is what happens in the case of cooperation. It involves an initial assumption that the parties have bound themselves to do whatever it takes to complete their contract. It is by no means a necessary assumption. Is it a reasonable one?

\section{AN IMPROPER OVERGENERALISATION OF AUTHORITY}

Let us return to Mackay $v$ Dick ${ }^{42}$, a case that concerned the proper construction of a contract for the sale of an excavating machine. In the early stages of Lord Blackburn's judgment, the force of his argument was that where cooperation is necessary, it is implied that it will be forthcoming. However, Lord Blackburn went on to say that

[t] he defender, having had the machine delivered to him, was by his contract to keep it, unless on a fair test according to the contract it failed to do the stipulated quantity of work, in which case he would be entitled to call on the pursuers to remove it. And by his own default he can now never be in a position to call upon the pursuers to take back the machine, on the ground that the test had not been satisfied, he must, as far as regards that, keep, and consequently pay for it. ${ }^{43}$

So even though the principle enunciated by Lord Blackburn has laid the foundations of the promissory approach to cooperation, in his analysis of the facts of the case there is no mention of prevention whatsoever. 'In his reasoning there was no question of the buyer preventing the sellers from claiming payment. He prevented himself from escaping from the liability to pay.' ${ }^{3}$

The inclusion in the contract of a term providing for the testing of the machine was obviously in the sellers' best interest, insofar as for them it was

able - such implication was destined to fail because there were a number of different ways in which the clause might be varied so as to provide for the event of the completion of phase I being delayed. Where there is no initial default solution, the test of necessity makes no sense. The test is quite inappropriate when the question before the court may be answered in any one of a number of alternative ways, and none of those ways is a clear prima facie choice. See JF Burrows 'Implied terms and presumptions' (1968) NZULRev 121. See n 26 above.

42 (1881) 6 App Cas 251 (HL).

43 Same case 264.

44 Mona Oil Equipment v Rhodesia Railways 1949] 2 All ER 1014, 1018 (Devlin J). 
highly advantageous 'to have the question, whether it was or was not conform to contract, determined by reference to a simple and definite test, instead of being left to the uncertainty of speculative opinion, aggravated by the risk of litigation. ${ }^{45}$ However, once agreed to, that term was technically for the benefit of the buyer, who was required to cooperate in order to take advantage of it. He did not cooperate, hence was not entitled to the benefit of returning the machine. '[T] he sale and delivery of the machine must in Mackay $v$ Dick be deemed to have been complete, and payment of the price was therefore subject only to the "resolutive condition" imposed by the clause as to the test.' 46

By failing to allow the testing of the machine to occur, the buyer was not in breach of contract, inasmuch as his conduct was of no consequence to the sellers whatsoever. They had not bargained for a right to demand performance of the test, why should they? The buyer was the only one who stood to gain by allowing the test to take place.

The duty to cooperate is imposed only for the purpose of giving full effect to the contract. Accordingly a party does not infringe the duty to cooperate by failing to perform an act which it has not undertaken to perform and is of no interest to the other party, for example, a failure to accept a tender of performance by the other party where that failure is of no consequence to it. 47

In short, it is submitted that the better view is that in Mackay $v$ Dick the buyer was not bound to cooperate by allowing the testing of the machine to occur. He had a choice either to cooperate or to suffer the consequences of his lack of cooperation. Hence even though Lord Blackburn used the language of implied terms strictly speaking he need not have done it, for characterising the buyer's conduct as wrongful - as a breach of contract - adds nothing to the solution of this problem.

\section{E. Discharge through LACK OF COOPERATION}

In many other cases there is equally no need to resort to the duty-based approach to cooperation, for there is a simpler way of allocating the risks involved. To take a particularly illustrative set of circumstances, where in a

\footnotetext{
45 Mackayv Dick (1881) 6 App Cas 251 (HL) 270-1 (Lord Watson).

46 Colleyv Overseas Exporters [1921] 3 KB 302, 308.

$47 \mathrm{O}$ Lando and H Beale Principles of European Contract Law (Kluwer Law International The Hague London Boston 2000) 120.
} 
building contract it is provided that the work shall be completed by a certain day and that liquidated damages shall be payable for any delay, the general rule is that the building owner will be unable to recover such damages if he orders extra work to be done which necessarily delays completion. ${ }^{48}$ Is this a breach of contract, though?

According to Stoljar, there are two principles at work in this type of case: the principle of prevention excusing the condition that makes payment dependent upon completion according to the term in question; and the principle of cooperation which imposes an additional duty upon the owner not to make the builder's performance more onerous - a breach of this duty creates a further liability in damages over and above the contract price. ${ }^{49}$ But where is the duty to cooperate in order to facilitate performance of the bargain? There is none.

A breach of contract is a breach of a duty arising under the contract, it is 'committed when a party without lawful excuse fails or refuses to perform what is due from him under the contract, performs defectively or incapacitates himself from performing. 50 So the question whether or not a particular contract has been broken depends primarily upon the precise construction of its terms. Where there is no duty to be broken, there is no breach of contract.

It is essential that one meticulously separates what is a breach from what is not, for ' $[w]$ hen it comes to the law's response to the facts, there is a crucial difference between a wrong and a not-wrong. The label 'wrong' operates as a licence to the law to mistreat the wrongdoer.'51 In order to decide whether there has been a breach of contract, it is necessary to ask: first, what exactly the parties have obliged themselves to do; and secondly, whether there are any good reasons for imposing an obligation on them which they have not voluntarily assumed.

48 See Holme v Guppy (1838) 3 M\&W 387; 150 ER 1195; Macintosh v The Midland Counties Rly (1845) 14 M\&W 548; 153 ER 592; Russell v Sá da Bandeira (1862) 13 CB(NS) 149; Westwood v Secretary of State for India (1863) 7 LT 736; Roberts v Bury Improvements Commissioners (1870) LR 5 CP 310; Jones v St John's College, Oxford (1870) LR 6 QB 115; Dodd v Churton [1897] 1 QB 562 (CA); Trollope \& Colls v North West Metropolitan Regional Hospital Board [1973] 1 WLR 601; Astilleros Canarios SA $v$ Cape Hatteras Shipping Co [1982] 1 Lloyd's Rep 518.

49 See SJ Stoljar 'Prevention and co-operation in the law of contract' (1953) 31 CanBarRev 231, 238.

50 GH Treitel The Law of Contract (10th edn London Sweet \& Maxwell 1999) 772.

51 P Birks 'Rights, wrongs and remedies' (2000) 20 OJLS 1, 33.

52 See 13 above. 
In my view a party's failure to cooperate constitutes a breach of contract only where the other party has legitimate expectations as to the purpose of that specific act of cooperation. In the cinema ticket example ${ }^{52}$, for instance, the theatre owner might well have been eager for that specific customer to watch the film. However, he had not bargained for the right to demand that the customer watch the film, nor was there any reason why a court should impose such an obligation on the customer, so the theatre owner's expectations are, in that respect, wholly irrelevant.

Let us examine for a moment the decision of the Court of Appeal in Dodd $v$ Churton. ${ }^{53}$ This case is within the general rule by which, if the building owner by ordering extras has prevented the performance of the work by the specified date, he has deprived himself of the right to claim the penalties provided for non-completion by that date. However, it is in this case particularly obvious that this is so regardless of fault, regardless of whether one is in the presence of a breach of contract. For in this case the building owner was undoubtedly entitled to order those extras, inasmuch as he had the express contractual right to do so. Even though he had not broken the contract, it was clear that he had to bear the risk of delay himself. Consequently, by ordering those extras he lost the right to claim liquidated damages for the untimely completion of the work.

The same goes for any case in which the courts have decided that one of the parties is discharged from a given duty because the other has actively or passively prevented him from performing that duty - the concept of breach is under those circumstances entirely unnecessary.

\section{F. THE CONCEPT OF A 'BURDEN'}

In the types of case previously discussed it is therefore inaccurate - and even dangerously misleading - to describe cooperation as a contractual duty, and it is quite surprising that such usage of the word 'duty' has so far survived. Indeed, one cannot but frown at the manifest inconsistency of the courts' behaviour when, on the one hand, they summarily reject a duty to act in good faith on the ground that it would be inherently repugnant to the adversarial ethic upon which English contract law is allegedly premised ${ }^{54}$, whilst on the other hand imposing duties to cooperate in order to facilitate the fulfilment of 'the bargain', regardless of whose contractual expectations are at stake, as

\footnotetext{
53 [1897] 1 QB 562 (CA).

54 See Lord Ackner's speech in Walford v Miles [1992] 2 AC 128 (HL).
} 
though that adversarial ethic had suddenly vanished and the parties' purposes in contracting had become identical.

It seems that, whereas each contractual party has (arguably) the duty to cooperate so as not to frustrate the other party's legitimate expectations, when it comes to his own legitimate expectations that party is merely faced with a choice between two alternative courses of action, both of which are lawful: he may decide either to cooperate and fulfil his expectations or not to cooperate and suffer the consequences of his own lack of cooperation. It is submitted that, insofar as the latter type of expectation is concerned, the concept of a 'burden' 55 - rather than that of a duty - is much better suited to encapsulate the true meaning of the requirement of cooperation.

The concept of a burden might at first sight appear as somewhat unfamiliar in the eyes of an English contract lawyer. ${ }^{56}$ However, if one takes a closer look at the doctrine of mitigation, one will soon come to the conclusion that the reality behind that concept is in fact all too familiar, even if not put in these terms. Indeed, every English contract lawyer will readily admit that the so-called 'duty to mitigate' is no real duty at all, ${ }^{57}$ in that a failure to mitigate does not result in the imposition of liability upon the innocent party. It rather 'operates pro tanto as a conditional bar to the recovery of damages 58 . In other words, the innocent party is given the choice either to conduct himself according to the canons of mitigation and subsequently recover his loss by way of an award of damages, or alternatively to behave in whichever way he pleases and bear the loss he may thus suffer himself. This is none other than a burden to mitigate.

To sum up, whenever a contracting party's withdrawal of cooperation is of no consequence to the other party, in that it is solely concerned with his own

55 See, as to the concept of burden in German law, R Schmidt Die Obliegenheiten (Versicherungswissenschaft Karlsruhe 1953) and K Larenz and M Wolf Allgemeiner Teil des bürgerlichen Rechts (8th edn Munich 1997) 264.

56 At least insofar as substantive law is concerned. There is, of course, the long-established concept of 'burden of proof' in procedural law.

57 See GH Treitel The Law of Contract (10th edn Sweet \& Maxwell London 1999) 910 and Remedies for Breach of Contract: a comparative account (repr pbk OUP Oxford 1991) 179; MG Bridge 'Mitigation of damages in contract and the meaning of avoidable loss' (1989) 105 LQR 398, 399. See Koch Marine v D'Amica Societá Di Navigazione ARL (The Elena D'Amico) [1980] 1 Lloyd's Rep 75, 88; Sotiros Shipping Inc and Aeco Maritime SA v Sameiet Solholt (The Solholt) [1983] 1 Lloyd's Rep 605 (CA) 608; Empresa Cubana Importada de Alimentos "Alimport" v Iasmos Shipping Co SA (The Good Friend) [1984] 2 Lloyd's Rep 586, 597; Sealace Shipping Co v Oceanvoice (The Alecos M) [1991] 1 Lloyd's Rep 120 (CA) 124.

58 MG Bridge 'Mitigation of damages in contract and the meaning of avoidable loss' (1989) 105 LQR 398, 399. 
legitimate contractual expectations, that party will not be in breach of a duty to cooperate. He will have been subject to the burden of deciding whether to cooperate and fulfil those expectations or not to cooperate and watch them remain unfulfilled. That is, in a nutshell, the essence of a burden: the incentive to act in a certain way by way of the attachment of a number of negative consequences to every other possible course of action without at the same time labelling those alternative modes of conduct as civil wrongs - without characterising them as instances of unlawful behaviour.

\section{CHAPTER II \\ A CONDITIONAL APPROACH TO COOPERATION}

\section{A. Contractual Risk-ALlocation}

It is commonly thought by English contract lawyers that whenever an event which was contractually expected to occur does not actually occur (or vice-versa) the party who bears that risk is in breach of contract, and is therefore liable for any loss which is caused by that non-occurrence. Taking the risk of this non-occurrence is therefore generally considered to entail a promise that it will occur. Where it is not possible to place the risk of the relevant non-occurrence on either party, it is widely understood that the contract is frustrated. However, there is a substantial difference between contractual risk-allocation and the scope of contractual promises (the duties involved).

As regards contractual risk-allocation, two significant trends can be perceived ${ }^{59}$ : whereas what may be called 'performance risks' are usually allocated to the promisor, the promisee normally takes what may be labelled 'fruition risks'. Indeed, as to the former, it can generally be said that a change of circumstances that only upsets the way in which a promisor is to carry out his promise is a risk taken by him alone. By and large, a person who undertakes to do something takes the risk that performance of his undertaking may prove more onerous than expected, or even impossible (his efforts towards performance may then be lost). By way of illustration, if I agree to drive someone to

59 See PS Atiyah An Introduction to the Law of Contract (5th edn OUP Oxford 1995) 240-243. Compare JB Machado 'Risco contratual e mora do credor' (1985) 116 RJL 194 as to Portuguese law. 
the airport every Saturday morning of the year 2002 in exchange for a fixed sum I take the risk of any sudden rise in the price of petrol.

Similarly, as regards fruition risks, the promisee takes the risk of any change of circumstances that disturbs his own individual purposes in contracting - he runs the risk that performance will in the end not be suitable to fulfil his needs, or that he will not be able to benefit from it due to some failure in his personal plan of action. Carrying on with the same example, my passenger will bear the risk that his need to take weekly flights will cease to exist, or that on any given occasion he might be unable to travel due to illness.

The latter type of risk is the one that this dissertation is mostly concerned with. As far as R's part in implementing the contractual plan is concerned, we are dealing with a risk that is generally allocated to $\mathrm{R}$ himself. Ordinarily, therefore, $\mathrm{P}$ should be able to count on R's cooperation, and should not be made to suffer the consequences of a lack thereof, be it deliberate or involuntary. Nonetheless, it does not inexorably follow that prevention should always be characterised as a breach of contract. It is possible for a contracting party to agree to bear the risk of a given event not taking place, without at the same time promising that it will (and vice-versa): that party merely agrees to bear the consequences of its non-occurrence; no breach, no wrongdoing.

Indeed, where one takes the risk that a certain event will take place, either (a) the occurrence of that event is for the other party's benefit, in which case bearing the risk means promising that it will happen - thus its non-occurrence will normally give rise to an award of damages; or (b) it is not for the other party's benefit, in which case bearing the risk means suffering the consequences of its non-occurrence (generally speaking - but not necessarily the non-fulfilment of one's own contractual expectations) without being excused from performing one's own part of the contract. ${ }^{60}$ This is typically the case of insurance contracts: the insured takes the risk that the event insured against may never occur, yet he never promises that it will - in fact he usually promises not to contribute in any way to the happening of the event insured against - and in any case he is still liable for his own part of the contract, that is, payment of the agreed premium.

To a certain extent, however, whether one can say that the taking place of the event is for one or the other party's benefit is highly dependent on whether a promise was made in the first place, which means that for the most part

60 This is in no way connected to the civilian doctrine of the fictional fulfilment of a condition (see 35 below). The reason one is not excused from performing one's own part of the contract is that one's duty to perform is independent from the happening of the event, not that the event is deemed to have happened. 
this is solely a question of arriving at the proper construction of a contract. But one thing is clear: the making of a contractual promise is not the only legal means of taking upon oneself a given contractual risk. There are other ways of doing it, above all that of resorting to the concept of condition instead.

\section{B. INTRODUCING THE CONCEPT OF CONDITION}

In certain types of contract, such as all kinds of insurance (except life insurance) and some contracts of guarantee, the promisee only bargains for a conditional duty of performance in that he bears the risk of the other party's performance never becoming due. How does he bear this risk? By still being liable to perform his part of the contract.

In its proper sense the word 'condition' means some operative fact subsequent to acceptance and prior to discharge, a fact upon which the rights and duties of the parties depend. Such a fact may be an act of one of the two contracting parties, an act of a third party, or any other fact of our physical world. It may be a performance that has been promised or a fact as to which there is no promise. 61

The former is usually called a promissory condition, the latter a contigent condition. Hereafter I shall reserve the word 'condition' to mean contingent condition, unless otherwise stated.

The type of condition that I am mostly interested in is that which consists of an act (or omission) of the promisee himself - in this case R - namely his active or passive cooperation aimed at facilitating P's performance. Such a condition could theoretically be characterised either as a condition precedent or as a condition subsequent to P's duty to supply his services to R. According to the first approach all that $\mathrm{P}$ would have promised would be to make his services available to $R$ and to execute whichever work $R$ enabled him to do under the circumstances. His duty to supply his services to R would be merely conditional, in that only by cooperating could $\mathrm{R}$ turn it into an immediate duty to effectively render his services.

However, it is my intention to explore the possibility of characterising such cooperation as a 'potestative' condition subsequent to P's duty to supply his services to $\mathrm{R},{ }^{62}$ for it is my belief that in the typical case this characterisation

61 AL Corbin 'Conditions in the law of contract' (1919) 28 YaleLJ 739, 743. Italics removed.

62 By 'potestative' condition I mean a condition whose fulfilment or non-fulfilment is primarily under the creditor's volitional control. See RJ Pothier Traité des 
NO RIGHT TO PERFORM A CONTRACT?

is better suited to adequately translate the true intention of the parties to a contract, in that at the outset both parties regard themselves as being bound to an immediate duty to conduct themselves in a certain way (that is, either to supply the agreed services or to pay the agreed price), and it is only after $R$ has decided not to cooperate that they are in need of a specific legal answer to their problem.

I shall hence be putting forward the view that $\mathrm{R}$ may have secured the discretionary power to release $P$ from his duty to supply his services by refusing to cooperate, and that $\mathrm{P}$ may have agreed to be under the correlative liability to have $\mathrm{R}$ thus wipe out his duty at will. ${ }^{63}$ This is, I may add, something entirely different from claiming that $\mathrm{P}$ has been released from the duty to perform his promise. As Montrose has once stated,

[i]t is usual to say that the failure of the event upon which a promise is conditional releases the promisor from liability to perform the promise. This is only true if promise is used as meaning the undertaking apart from the condition. The true position is that by doing nothing the promisor does perform his promise for he did not undertake to do anything in the event of a failure of the condition. 64

Obligations I (nouvelle édn Thomine et Fortic Paris 1821) 170-171. Pothier's classification of conditions into potestative, casual and mixed conditions, although followed in Scotland [see WM Gloag The Law of Contract: a Treatise on the Principles of Contract in the Law of Scotland (2nd edn Caledonian Books Collieston 1985) 276-281] and the civil law systems [see R Zimmermann The Law of Obligations: Roman Foundations of the Civilian Tradition (OUP Oxford 1996) 722], is not yet widely recognised in England. See, however, M Mark Chalmers' Sale of Goods (18th edn Butterworths London 1981) 372-3, for the observation that the classification of conditions in English law is imperfect and unsatisfactory, and that for accuracy some such subdivision is required.

${ }_{63}$ AL Corbin 'Conditions in the law of contract' (1919) 28 YaleLJ 739, 742. For the distinction between the right / duty relation and the power / liability relation see WN Hohfeld 'Some fundamental legal conceptions as applied in judicial reasoning' (1913) 23 YaleLJ 16, 28-32 and 44-54.

${ }^{64}$ JL Montrose 'Conditions, warranties, and other contractual terms' (1937) 15 CanBarRev 309, 316. See also OW Holmes The Common Law (Dover Publications New York 1991) 318, where the author uses words to the effect that the promisee's part of the contract is as truly kept and performed by doing nothing where the condition has not been fulfilled, as it would have been by rendering the services had the condition been fulfilled. 


\section{A DISCRETIONARY POWER TO COOPERATE?}

Ordinarily, upon entering a contract each contracting party will have a certain amount of interest in what the other party is offering, and must therefore be willing to cooperate in order to fulfil the bargain. As a result, the precise characterisation of the requirement of cooperation may not be very clearly stated. But in fact, had there been an officious bystander asking $\mathrm{R}$ whether he was truly committing himself to cooperate, perhaps he would say he was not. For, as previously remarked, there are other ways - over and above the making of a promise - of bringing about a certain desired action by another person.

It seems perfectly plausible that someone would wish to secure a contractual right to a given service without at the same time promising that he will accept it when the time comes, or that he will cooperate in order to enable the other party to supply it. To take a typical case, $\mathrm{P}$ and $\mathrm{R}$ enter a contract for the painting of a portrait. P's undertaking obviously depends upon R's cooperation. However, $\mathrm{R}$ does not necessarily wish to bind himself to cooperate. He may bargain for the right - not the obligation - to have his portrait painted. In other words, he may purchase P's time and skills - his availability without at the same time committing himself actually to benefit from them.

Surely R must be required not to make P's performance any more onerous than $\mathrm{P}$ should reasonably expect it to be at the time of contracting. Nonetheless, should $\mathrm{R}$ decide not to cooperate at all, what happens is that P's duty effectively to paint the portrait never becomes due, inasmuch as he has been released before it ever did. It is as simple as that. Of course, $\mathrm{P}$ must under no circumstances be injured by this situation. Where he has bargained for the full contract price, his expectation to receive it should somehow be protected. The difficulty with the present submission is that, as the law currently stands, the protection of P's expectation to the full contract price appears to be utterly irreconcilable with the recognition of R's choice not to cooperate.

\section{THE OBSTACLE: A RIGHT TO PERFORM}

The main obstacle to the submission that $\mathrm{R}$ might under some circumstances have bargained for a discretionary power to cooperate - rather than having promised to do so - seems to be the widely accepted requirement that $P$ must earn his right to the full contract price by actually supplying his services to $R$. This requirement effectively calls for the recognition of P's right to earn the full contract price, that is, a right to supply his services to $\mathrm{R}-$ in 
NO RIGHT TO PERFORM A CONTRACT?

essence, a right to perform his part of the contract. ${ }^{65}$ As long as one sustains the view that by preventing $P$ from supplying his services $R$ will also be preventing him from earning his right to the full contract price, there is no way of contending that $\mathrm{R}$ should be recognised such a discretionary power, for its exercise would automatically injure P's legitimate contractual expectations. ${ }^{66}$

At first sight the so-called doctrine of the fictional fulfilment of conditions appears to offer a way out. As Lord Watson observed in Mackay v Dick:

The respondents were only entitled to receive payment of the price of the machine on the condition that it should be tried at a proper working face provided by the appellant, and that on trial it should excavate a certain amount of clay or other soft substance within a given time. They have been thwarted in the attempt to fulfil that condition by the neglect or refusal of the appellant to furnish the means of applying the stipulated test; and their failure being due to his fault, I am of opinion that, as in a question with him, they must be taken to have fulfilled the condition. ${ }^{67}$

In the situation under analysis, an application of the doctrine of the fictional fulfilment of conditions would entail that, whenever R 'culpably' prevented $\mathrm{P}$ from actually supplying his services by withdrawing his cooperation, P's performance must be deemed to have been completed, and his right to the full contract price thereby taken to have been duly earned. However, it has been repeatedly stated by both judges and academics that this doctrine - which derives from a principle of civil law that was later imported into Scottish law - is definitely not part of English law. ${ }^{68}$ Indeed, English law typically

${ }^{65}$ While the idea of a 'right to perform' is not habitual in English discussions, see S Whittaker 'Performance of another's obligation: French and English law contrasted' (2000) OUCLF 7 at ouclf.iuscomp.org. For a discussion of this subject in Portuguese law see JC Silva Cumprimento e Sanção Pecuniária Compulsória (reprint 2th edn SBFDUC Coimbra 1997) 116 and FAC Sá Direito ao Cumprimento e Direito a Cumprir (Almedina Coimbra 1997).

${ }_{66}$ See PM Nienaber 'The effect of anticipatory repudiation: principle and policy' [1962] CLJ 213, 224; F Dawson 'Metaphors and anticipatory breach of contract' [1981] CLJ 83, 96. See, however, Anon 'Anticipatory breach: right of plaintiff to perform' (1963-66) 2 AdelLRev 103, 112 for the suggestion that the nature of a contract and the circumstances of its inception 'be scrutinised in order that the court may determine whether it was within the intention of the parties that if one party repudiates, the other should have a right to perform in addition to his remedy in damages'.

${ }^{67}$ Mackay v Dick (1881) 6 App Cas 251 (HL) 270. See also Scott J's analysis of this case in Thompson $v$ Asda-MFI Group plc [1988] Ch 241, 252-253.

68 That this is so is not disputed, at least not since the decision in Laird v Pim (1841) 7 M\&W 474; 151 ER 852. See also Thompson v Asda-MFI Group plc [1988] Ch 
deals with this particular problem through the remedy of an award of damages for breach of contract. ${ }^{69}$

Moreover, this doctrine contains an unattractive element of punishment, inasmuch as it constitutes the law's response to what is essentially characterised as a breach of contract - its operation is always triggered by what is considered to be an unlawful conduct. So for the purposes of this dissertation it is entirely unhelpful. Hence in order to sustain the view that R should lawfully be able to prevent $\mathrm{P}$ from supplying his services by choosing to withdraw his cooperation, one must first do away with the thought that contractual parties must have the right to perform their own part of the contract so as to be in a position to claim their right to the counter-performance.

\section{E. THE HIDDEN ASSUMPTION STRIKES AGAIN}

The requirement that $\mathrm{P}$ must earn his right to the full contract price by duly supplying his services is far from universal. In fact, in cases such as that of the cinema ticket, everyone will readily admit that $\mathrm{R}$ is free to decide whether to turn up and watch the film or do something else instead. The reason why such a requirement has never been considered in this type of case seems to be that under those circumstances there is no room for the question whether P must earn his right to the full contract price, inasmuch as that price is payable in advance at the box office - a right cannot be conditional where it is already due. But why do courts impose this requirement in every other case?

The truth is, when coming across a contract for the supply of services, the courts have consistently been taking for granted that $P$ must without question earn his right to the full contract price by duly supplying his services to $\mathrm{R}$ before he becomes entitled to claim it. Indeed, they start off by embracing the dogma that P's right to the full contract price is conditional upon the actual supply of services only to arrive at its logical consequence: whenever R's cooperation is necessary to facilitate that supply of services, it cannot possibly be discretionary, since the recognition of any discretion on the part of $R$ would inexorably injure P's legitimate contractual expectations. At this stage

241, 266; Little v Courage Ltd (1995) 70 P\&CR 469, 474. See also GH Treitel 'Fault in the common law of contract' in B Maarten and I Brownlie (edd) Liber Amicorum for the Rt Hon Lord Wilberforce (OUP Oxford 1987) 185.

69 See Inchbald y Western Neilgherry Coffee, etc, Co (1864) 17 CB (NS) 733; Colley v Overseas Exporters [1921] $3 \mathrm{~KB}$ 302, 309; Bournemouth \& Boscombe Athletic FC $v$ Manchester United FC The Times May 221980 (CA); Alpha Trading v Dunnshaw-Patten [1981] QB 290 (CA). 
NO RIGHT TO PERFORM A CONTRACT?

it is apparent that one has come across another one of the courts' hidden assumptions.

As has been previously stated, the so-called duty to cooperate is allegedly imposed solely for the purpose of giving full effect to the contract. Accordingly a party does not infringe it simply by failing to perform an act that is of no consequence to the other party. ${ }^{70}$ However, in order to determine whether or not such an act is of consequence to the other party one needs to find out whether, upon a proper construction of the contract, P's right to the full contract price in any way depends on R's cooperation in the first place. What is the point of stating that the duty to cooperate will only be infringed where the withdrawal of cooperation is of consequence to the other party, if one is going to start off by assuming that it always will be? It is submitted that, at least in some cases, $R$ does no harm by refusing to cooperate - the law does, by taking for granted that P's right to the contract price is always conditional upon his actual supply of services.

\section{F. P'S EXPECTATION TO THE FULL CONTRACT PRICE}

In order to reach a reasonable solution to this problem it is therefore essential that one takes a close look at the contract under analysis and at its surrounding circumstances and then attempts to determine what exactly each party has bargained for and the exact scope of their rights and duties. ${ }^{71}$ In this respect, one must just ask: did $\mathrm{P}$ in this particular factual situation take the risk that $\mathrm{R}$ might be unwilling to cooperate?

In some cases - for instance those of the estate agent's commission ${ }^{72}$ - one will most probably reach the conclusion that he did, for it is now beyond dispute that, unless otherwise stated, should $\mathrm{R}$ decide not to go through with the sale $\mathrm{P}$ is left with nothing. In this situation, the recognition of R's discretionary

70 See O Lando and H Beale Principles of European Contract Law (Kluwer Law International The Hague London Boston 2000) 120, quoted 26 above.

71 See Prenn $v$ Simmonds [1971] 1 WLR 1381 (HL) 1385 (Lord Wilberforce); Reardon Smith Line Ltd v Yngvar Hansen-Tangen [1976] 1 WLR 989 (HL) 995-6 (Lord Wilberforce); Chatenay v Brazilian Submarine Telegraph Co [1891] 1 QB 79 (CA) 85.

72 See Luxor (Eastbourne) Ltd v Cooper [1941] AC 108 (HL) - see 24 above. See also Rhodes $v$ Forwood (1876) 1 App Cas 256, 272, 274; Hamlyn \& Co $v$ Wood \& Co [1891] 2 QB 488 (CA) 493 and Lazarus v Cairn Line of Steamships (1912) 17 Com Cas 107,114 where the courts refused to imply a term that the principal in an agency agreement would not, by going out of business, deprive the agent of a chance to earn his commission. 
power to decide whether to cooperate or not to cooperate is uncontroversial: P's right to his commission is subject to a potestative condition ${ }^{73}$, and it is totally up to R either to fulfil it or not.

In other cases, reaching a definitive conclusion on this matter will not be as straightforward. In Bournemouth \& Boscombe Athletic FC v Manchester United $F C^{74}$, a professional footballer was transferred for a fee, a small part of which was to be paid only after he had scored twenty goals for the new club. Before he had done so, the club hired a new manager, who in turn decided to drop him from the first team. The Court of Appeal held that the defendants were in breach as they failed to give the player a reasonable opportunity to score the twenty goals. In short, they regarded this situation as one of deferred remuneration. However, there is certainly room for the view that, on a proper construction of this contract, the risk that the player might never be able to fulfil the condition should have been borne by the claimants. Indeed, it is extremely difficult to imagine that a football club of the defendants' standing would, when 'buying' a virtually unknown player off a modest third division club, commit itself to such an unusual term - a term which meant that they were effectively bound to keep him in the first team for a reasonable period of time, in order to give him 'a fair chance' of scoring those twenty goals. Hence, not only was the implication of this term wholly unnecessary, it was also fairly unreasonable, according to the most elementary commercial criteria.

In the vast majority of cases, however, one will promptly come to the conclusion that $\mathrm{P}$ did not take the risk that $\mathrm{R}$ might be unwilling to cooperate, in that he has bargained for the right to the full contract price. Where that is the case, his expectation to be paid the full contract price is wholly legitimate and must therefore be adequately protected. Sure enough this right is usually conditional upon his duly performing his part of the contract (condition is being used here in its promissory sense). But what exactly does his part of the contract consist of? That is the next question in need of a clear answer.

By and large, two different techniques may be employed in order to protect P's expectation to the full contract price, each of them operated by one of two possible and fairly diverse approaches to cooperation: (a) the promissory approach to cooperation; and (b) the conditional approach to cooperation. For, as Corbin once stated, 'both a promise and a condition are means that are used to bring about a certain desired action by another person. ${ }^{75}$ The

\footnotetext{
73 See $n 62$ above.

74 The Times May 221980 (CA).

75 AL Corbin 'Conditions in the law of contract' (1919) 28 YaleLJ 739, 746.
} 
former is the one taken up by the courts when implying their duties of cooperation. Its rationale and modus operandi have been sufficiently outlined in Chapter One.

The promissory approach to cooperation can be quite useful in circumstances such as those in Fechter $v$ Montgomery ${ }^{76}$, a case where the manager of a London theatre engaged a theatre performer at a salary for two years and it was held that the manager was under an implied duty to give the actor a reasonable opportunity to appear on stage. Indeed, in this type of case both parties have an obvious contractual interest in securing such an appearance. One might say that here the consideration is not just the money - it is the money plus the opportunity to enhance P's professional reputation. ${ }^{77}$ The same could be said of a case such as Planché $v$ Colburn $^{78}$, where $\mathrm{P}$ agreed to write a book on costume and ancient armour that was to be published in serial form in R's periodical. Similarly, taking up once again the example of the artist who is engaged to paint someone's portrait, where that someone happens to be a celebrity one could easily imagine that both parties will have entered the contract with a view to securing the actual completion of the portrait itself.

Nonetheless, in most other cases $\mathrm{P}$ will have no direct interest in performing his part of the contract. His interest in his own performance will lie solely in its being the only means of securing his right to the counter-performance - the payment of the full contract price. Whenever that is the case, one can equally adopt a conditional approach to cooperation and resort to the second technical device designed to protect P's expectation to the full contract price, namely that of characterising the requirement of cooperation as a contingent condition (subsequent) to P's duty to supply his services to R.

According to this approach, $\mathrm{R}$ has the power - not the duty - to cooperate with $\mathrm{P}$ and thereby tie him to his duty to effectively render his services. The exercise of this power is discretionary: he has a choice either to cooperate and fulfil his own contractual expectations or not to cooperate and fail to earn his right to the services he bargained for, whilst still being bound to perform his own part of the contract - the payment of the full contractual price.

76 (1863) 33 Beav 22. See also Marbé v George Edwardes (Daly's Theatre) Ltd [1928] 1 KB 269; Herbert Clayton \& Jack Waller v Oliver [1930] AC 209 (HL).

77 'The consideration which was promised to Mr Montgomery... is twofold, he was to receive seven guineas a week, and was to have an opportunity of shewing what his abilities were before a London audience.' Same case 29. In this case the contract was an employment contract, but it is submitted that the same rationale applies, mutatis mutandis, to the case of a contract for the supply of theatrical services.

78 (1831) 8 Bing 14; 131 ER 305. 


\section{MARGARIDA LIMA REgo}

In short, rather than imposing duties of cooperation, this approach works by imposing what has previously been described as a "burden" 79 : $\mathrm{R}$ is absolutely free to choose whether or not to cooperate. Either way his conduct will be perfectly lawful. However, he must bear the consequences of whichever course of action he ends up taking. To put it another way, he is free to renounce the benefit of the contract, but he must cooperate if he wishes to have it.

\section{G. WHAT EXACTLY IS AT STAKE HERE?}

In the latter group of cases one starts off with the need to choose between these two very different approaches to cooperation. This choice should not be made in the abstract, for its outcome should ultimately depend on the proper construction of the contract under analysis. However, so far the courts have been following the promissory path without even realising that there is a choice to be made. In my view this state of affairs is not wholly satisfactory. I shall proceed my line of reasoning by taking a closer look at the alternative approaches from each contracting party's own standpoint.

Let us take P's side to begin with. If one follows the promissory approach such as it has been adopted by the courts ${ }^{80}$ and decides that $\mathrm{R}$ is under a duty to cooperate in order to facilitate P's supply of services and that $\mathrm{P}$ will only be able to claim the full contract price if he does supply his services, financially speaking his only remedy in the event of non-performance due to R's lack of cooperation will be an award of damages. Alternatively, if one follows the conditional approach to cooperation, whilst $\mathrm{R}$ will be under no duty to cooperate, P's right to the full contract price will in no way depend on the materialisation of such cooperation. If it does not materialise $\mathrm{P}$ will still be entitled to claim the full contract price. ${ }^{81}$

From P's standpoint, the latter is a much more advantageous cause of action than the former. Moreover, it makes his position much clearer, in that the issue of the standard of R's duty to cooperate does not even occur. Should

\footnotetext{
79 See 28-30 above.
}

80 Theoretically, one could also follow the promissory approach to cooperation and simultaneously argue that $P$ 's right to the full contract price does not depend on the actual supply of services, given that these views are not mutually exclusive. I shall not, however, dwell on such an unlikely hypothesis, for it shares all of the conditional approach to cooperation's disadvantages without at the same time partaking of the bulk of its advantages.

8. Even though, at the end of the day, the amount he ends up receiving might be inferior to the full contract price. See 59-61 below. 
one follow the duty-based approach to cooperation, one might be lured into believing in the sort of reasoning which contends that all $\mathrm{R}$ is required to do is exercise his duty to cooperate with due diligence, ${ }^{82}$ whereas the burden-based approach to cooperation makes it crystal clear that this is purely a matter of risk-allocation, where fault is irrelevant, and that consequently, should there be any problem whatsoever regarding R's cooperation, he will be the one to suffer its negative effects - not P.83 Therefore it would appear that, if given a choice, $\mathrm{P}$ would gladly opt for the conditional approach to cooperation.

As for $\mathrm{R}$, at this stage it is already fairly conspicuous that it would be in his best interest to follow the conditional approach to cooperation, for he would in fact be choosing between binding himself to a duty on the one hand and obtaining a discretionary power on the other hand. Securing his right to P's services without at the same time binding himself to cooperate in order to facilitate P's performance would undoubtedly be the better deal. Nonetheless, as far as R's position is concerned, the full extent of this approach's superiority will not be fully apparent until later on in my argument. ${ }^{84}$

\section{H. WHAT THE PARTIES HAVE TRULY PROMISED TO DO}

Hence, at least in theory, in a fair number of cases it will be in both parties' best interest to stick to a conditional approach to cooperation. Ultimately, however, this matter will turn on the proper construction of each individual contract. What must in every particular case be determined is whether, all things considered, one should reach the conclusion that $\mathrm{P}$ has a genuine right to perform the services he has contracted to supply, and conversely whether R's commitment extends to an obligation to allow and even facilitate P's supply of services, or whether it is confined to the obligation to pay him the agreed remuneration.

Generally speaking, would it make sense for $\mathrm{P}$ to bargain for a right to perform such services - bearing in mind the extra transaction costs that this would entail - where in most cases he has no interest in actually performing his part of the contract, given that his only interest in performing lies in securing his right to the counter-performance - the payment of the full contract

82 See Anon 'Unilateral contract law - an analysis in terms of conditions' (1933) 33 ColLRev 463, 473-5 and cases cited therein.

83 By way of illustration, see Dodd v Churton [1897] 1 QB 562 (CA). See 28 above.

84 See 59-69 below. 
price? As has already been demonstrated, only in the leading actor type of case - where actual performance is part of the bargain, together with the price - is the adoption of the promissory approach prima facie more appropriate than the conditional one. Why bargain for the right to perform unless one cannot wholly fulfil one's contractual expectations without it? I believe that quite often such a right has in fact not been (expressly or implicitly) bargained for.

In my view, if one takes a fresh and open-minded look at each particular factual situation, one undoubtedly finds that, in some (if not all) of those cases, $\mathrm{R}$ will not have committed himself to cooperate. At the very least, one will surely not come across anything that decisively points towards the conclusion that he did. Whenever this is the case, if one also concludes that $\mathrm{P}$ did not take the risk that R's cooperation would not materialise, what must logically follow is that whenever $\mathrm{R}$ chooses not to cooperate $\mathrm{P}$ must be released from his duty to render his services to him whilst retaining his right to the full contract price. Returning to one of our previously mentioned examples, it is submitted that in some (if not all) cases one will find that $\mathrm{P}$ will not have promised to paint the portrait; he will have promised to paint the portrait provided he can count on R's cooperation.

To sum up, if P's performance is conditional upon something that is at R's discretion - R's cooperation - and P's right to earn the contract price is not regarded as being conditional upon that same thing (the fact that he is currently recognised the right to an award of damages proves that it is not), the only possible result of the adding up of both of these premises is that P's right to the full contract price must not be made dependent upon the actual supply of his services to R. Thus the way may be cleared for an unprejudiced construction of each individual contract for the supply of services in the manner that best serves the parties' legitimate contractual expectations.

\section{CHAPTER III \\ THE RIGHT TO REJECT THE BENEFIT OF THE CONTRACT}

\section{A. WHAT IF NO COOPERATION IS NEEDED?}

In the previous chapter, I have argued that the parties must at the very least be recognised the freedom to decide whether or not they wish to commit themselves to cooperating with one another in the completion of the contract. Indeed, in accordance with what has been so far contended, the choice between 
either the promissory or the conditional approaches to cooperation is ultimately a matter for the proper construction of the individual contract, and it is therefore pretty much left to the parties themselves to decide how best to protect their own interests in each transaction.

Nonetheless, the recognition of a power to prevent another's contractual performance through the withdrawal of one's cooperation cannot provide $R$ with an answer to his problem in all those cases where $\mathrm{P}$ happens to be able to complete his part of the contract without R's cooperation and even against his will. It is in this context that the controversial decision of the House of Lords in White \& Carter (Councils) v McGregor ${ }^{85}$ comes into play.

In this case a majority of the House of Lords reached the seemingly logical and yet somewhat grotesque conclusion that whenever $P$ can perform his part of the contract without R's cooperation he has an unfettered right to do so in order to recover the full contract price as it becomes due. ${ }^{86}$ In doing so he may wholly disregard the fact that $\mathrm{R}$ is no longer interested in his performance, even where - subject to one important qualification ${ }^{87}$ - the services he is about to provide have turned out to be something entirely futile and of no value to anybody. Hence, as the law currently stands, in these circumstances R's hands are tied: whether he wants it or not, he has no choice but to endure P's services, should he choose to supply them. He has contracted for another to make his bed, now he must lie on it.

Thus

[i]f a customer deposits his clothes to be cleaned, and then cancels the order before the work has been carried out, the cleaner may nevertheless clean the clothes and demand the full contract price.... The girl whose fiancé declares that he will not be present on the agreed wedding day may nevertheless proceed to fill her bottom drawer in the hope that he will change his mind and in the knowledge that, if he does not, damages for breach of promise must take into account the expenditure incurred up to the agreed wedding date and not only up to the date of the repudiation of the engagement. ${ }^{88}$

85 [1962] AC 413.

86 In Hounslow London BC v Twickenham Gardens Developments [1971] Ch 233, 253 it was further clarified that such constraint would only apply to cases where no cooperation - either active or passive - was required in order for $\mathrm{P}$ to be capable of performing.

87 That is, unless it can be shown that he has 'no legitimate interest, financial or otherwise, in performing the contract rather than claiming damages'. White \& Carter (Councils) Ltd v McGregor [1962] AC 413 (HL) 431 (Lord Reid). For a careful analysis of this qualification see $54-59$ below.

88 Anon 'Contract: anticipatory breach and mitigation of damages' (1962) 233 Law Times 381. See Clark v Marsiglia (1845) 1 Denio 317 and Frost v Knight (1872) LR 7 Ex 111 for real-life examples of similar factual situations. 


\section{Margarida Lima Rego}

As previously stated, the focal point of my dissatisfaction with the White \& Carter case was R's utter powerlessness to prevent $P$ from supplying his services to him. In that sort of factual situation something which had typically been secured for R's sole benefit - his right to demand P's performance - may later turn out to have become entirely worthless or even potentially damaging to him and yet, according to the aforementioned decision, there is absolutely nothing he can do to prevent such performance from taking place. He lacks any control whatsoever over an act or omission whose sole purpose should have been to benefit him and him alone. Why should it be so?

\section{B. THE DOCTRINE OF ANTICIPATORY BREACH OF CONTRACT}

After a contract has been entered into but before the time fixed for performance has come one contracting party may repudiate it by letting the other party know that he does not intend to perform his part of the contract when it becomes due. This is called an anticipatory breach of contract. ${ }^{89}$ The current legal response to such sort of behaviour was first devised in 1853 in the case of Hochster $v$ De La Tour. ${ }^{90}$ Given that neither party has a right unilaterally to rescind a contract, the repudiation appears to be fictionally regarded as an invitation to rescind which the innocent party may choose to accept and immediately sue for damages if he sees fit; alternatively he may choose to wholly disregard it, in which case the contract remains in full effect, which accounts for Asquith LJ's famous aphorism, paraphrasing Keats, that '[a]n unaccepted repudiation is a thing writ in water and of no value to anybody.'91

The doctrine of anticipatory breach of contract was initially thought out to provide a party who had been told he would not get the benefit of the contract with an immediate remedy. This remedy, however, consisted in an option the injured party was obviously not under an obligation to terminate the contract, for that would amount to an acknowledgment that the repudiating

89 For a thorough account of the advent and development of this doctrine in English law see M Mustill 'Anticipatory breach of contract: the common law at work' in Butterworth Lectures 1989-90 (Butterworths London 1990) 1. For a comparative study of the same subject see S Whittaker 'How does french law deal with anticipatory breach of contract?' (1996) 45 ICLQ 662 and CF Almeida 'Recusa de cumprimento declarada antes do vencimento' in Estudos em Memória do Professor Doutor João de Castro Mendes (Lex Lisbon 1995) 289-317. Note that not every anticipatory breach of contract amounts to a repudiation of the contract.

90 (1853) 2 E\&B 678; 118 ER 922.

91 Howard v Pickford Tool Co [1951] KB 417 (CA) 421 (Asquith LJ). 
NO RIGHT TO PERFORM A CONTRACT?

party had the power to bring the contract to an end at will - something which might dangerously undermine the entire institution of contract as we know it. This is essentially why it must be left to the innocent party to decide whether to accept or to reject the repudiation.

In its inception, therefore, this doctrine was never intentionally aimed at allowing one party to wholly disregard the other party's position and to perform his part of the contract knowing only too well his performance to be fully unwanted and perhaps even potentially damaging to the latter. And yet this is what happens if one chooses to apply it to those cases where (1) the injured party's performance is supposed to precede that of the repudiating party and (2) the latter cannot prevent such performance by refusing to cooperate. Whenever this is the case an indiscriminate application of the doctrine of anticipatory breach of contract will have the effect of allowing $\mathrm{P}$ to render his services in the face of R's averred loss of interest: unable to prevent such performance from taking place, as the law currently stands $\mathrm{R}$ has no choice but to endure it.

In the White \& Carter case the respondents agreed to pay the appellants a fixed sum to have their garage business advertised for three years on plates attached to litter bins. Later the same day the garage owners repudiated the contract but the advertising contractors nevertheless displayed the plates and subsequently claimed the full contract price. A majority of the House of Lords upheld the claim..$^{92}$ The main reason given was that according to Hochster $v$ De La Tour repudiation did not of itself bring a contract to an end, but merely gave the injured party an option to terminate the contract. Since the advertising contractors chose instead to affirm it, the contract remained in full effect. The minority, on the other hand, essentially contended that a contracting party had no right to ignore another party's repudiation where specific performance was unavailable, and that the mitigation rules were applicable from the time of repudiation.

\section{MISSING THE POINT}

The House of Lords' decision in the White \& Carter case has been widely criticised by commentators from all quarters of the common law world. ${ }^{93}$ It is

92 Lords Reid, Tucker and Hodson (Lords Morton and Keith dissenting). The Scottish case of Langford \& Co $v$ Dutch 1952 SC 15, indistinguishable on the facts, was overruled.

93 See PM Nienaber 'The effect of anticipatory repudiation: principle and policy' [1962] CLJ 213; AL Goodhart 'Measure of damages when a contract is repudiated' 


\section{Margarida Lima Rego}

said to encourage wasteful performance leading to inefficient results, to be inconsistent with the principle of mitigation, to allow what amounts to an indirect specific performance of contracts that are not specifically enforceable, and more generally to reward what adds up, in essence, to unconscionable behaviour. It has not been followed in a number of other common law jurisdictions. ${ }^{94}$ Nonetheless, when browsing through the numerous commentaries that this decision has inspired, one often comes across remarks to the effect that in that decision ' $[t]$ here is an obvious tension between the impeccable logic of the majority and the intuitive sense of justice of the minority. ${ }^{2} 95$

Indeed, as regards the thoroughly scrutinised and somewhat worn out contention that the solution to this problem must lie in the principle of mitigation and its underlying policy - the desirability of avoiding waste - it is not uncommon even for its fiercest supporters to own up to some of its technical weaknesses. Above all they admit to the fact that, at any rate as conventionally applied, this principle is directed at the mitigation of loss arising from a breach of contract in view of the subsequent calculation of the measure of damages to be awarded so as to compensate the injured party for his unfulfilled contractual expectations. It should follow that the principle cannot be used to support the view that that party ought to relinquish his right to the

[1962] 78 LQR 263; MP Furmston 'The case of the insistent performer' (1962) 25 MLR 364; K Scott 'Contract - Repudiation - Performance by innocent party' [1962] CLJ 12; RG McKerron 'Effect of election not to accept anticipatory repudiation of contract: White \& Carter v McGregor' (1962) 79 SALJ 309; Anon 'Anticipatory breach: right of plaintiff to perform' (1963-66) 2 AdelLRev 103; SJ Stoljar 'Some problems of anticipatory breach' (1974) 9 MelULRev 355, 368; LJ Priestley 'Conduct after breach: the position of the party not in breach' (1990-91) 3 JCL 218; A Burrows Remedies for Torts and Breach of Contract (2nd edn Butterworths London 1994) 321-322; MP Furmston Cheshire, Fifoot \& Furmston's Law of Contract (13th edn Butterworths London 1996) 631.633; JW Carter, A Phang and SY Phang 'Performance following repudiation: legal and economic interests' (1999) 15 JCL 97. See, however, WED Davies 'Anticipatory breach and mitigation of damages' (1960-62) 5 UWAusLRev 576, 588-590; E Tabachnik 'Anticipatory breach of contract' [1972] 25 CLP 149, 164-172; F Dawson 'Metaphors and anticipatory breach of contract' [1981] CLJ 83, 106-107.

94 See Clark $v$ Marsiglia (1845) 1 Denio 317 and Rockingham County $v$ Luten Bridge (1929) 35 F 2d 301 (USA); Finelli v Dee (1968) 67 DLR (2d) 393 (obiter) and Asamera Oil Corp $v$ Sea Oil Corp (1979) 89 DLR (3d) 1 (Canada). See, however, 'The rule in White \& Carter (Councils) Ltd v McGregor' - a report by the Contracts and Commercial Law Reform Committee, presented to the New Zealander Minister of Justice on 5 May 1983 (New Zealand Law Society), for a somewhat ambiguous position as to the correctness of the White e Carter case.

95 JW Carter, A Phang and SY Phang 'Performance following repudiation: legal and economic interests' (1999) 15 JCL 97, 102. 
promised counter-performance and sue for damages for breach of contract instead, in order to reduce the amount of money that the breaching party would have to partake with if forced to perform his part of the contract. ${ }^{96}$

The argument here appears to be premised on the need to look to the substance rather than the form: while there is a logical distinction between an action for a debt and an action for breach (and hence between recovery of a debt and recovery of damages), the injustice that the doctrine of mitigation was intended to prevent is nevertheless the same (in substance) on facts such as the present where the action is in debt. 97

But to what extent are form and substance truly irreconcilable in the situation under analysis? Is it absolutely necessary for such basic conceptual distinctions as that of an action in debt and one for breach of contract to be mercilessly trampled over in order for the courts to achieve practical justice? Given the startling nature of such an assertion, one has no choice but to wonder: is the logic of the majority in the White \& Carter case so 'impeccable'?

One could always argue that P's conduct in ignoring R's best interests whilst supplying his services usually goes against the principle that contracting parties must comply with the requirement of good faith when performing and enforcing their contracts. Indeed, this line of argument has occasionally been followed in the US. ${ }^{98}$ However, one would most probably be faced with the contention that in English law there is no such thing as a general duty to comply with good faith. Not so long ago, Lord Ackner utterly rejected its existence (albeit in the context of pre-contractual negotiations), saying that the concept was both unworkable in practice and inherently repugnant to the adversarial ethic upon which English contract law is premised. ${ }^{99}$ Hence in

96 See Tredegar Iron \& Coal Co v Hawthorn Bros \& Co (1902) 18 TLR 716 (CA) 716; Shindler $v$ Northern Raincoat Co [1960] 1 WLR 1038, 1048. See WED Davies 'Anticipatory breach and mitigation of damages' (1960-62) 5 UWAusLRev 576.

97 JW Carter, A Phang and SY Phang 'Performance following repudiation: legal and economic interests' (1999) 15 JCL 97, 102.

98 See Clark $v$ Marsiglia (1845) 1 Denio 317, where it was first established that for $P$ 'to persist in accumulating a larger demand is not consistent with good faith'. See D Friedmann 'Good faith and remedies for breach of contract' in J Beatson and D Friedmann (edd) Good Faith and Fault in Contract Law (OUP Oxford 1997) 399, 421-425.

99 Walford $v$ Miles [1992] 2 AC 128 (HL) 138. On good faith in English law more generally, see J Steyn 'The role of good faith and fair dealing in contract law: a hairshirt philosophy' [1991] Denning LJ 131; JF O'Connor Good Faith in English Law (Darthmouth Publishing Co Aldershot 1991); R Goode "The concept of "good faith" in English law' (Centro di Studi e Richerche di Diritto Comparato e Straniero, Saggi, 
English case law one will often find statements to the effect that '[a] person who has a right under a contract or other instrument is entitled to exercise it and can effectively exercise it for a good reason or a bad reason or no reason at all.' 100 Or, in Lord Reid's own words in the White \& Carter case, '[i]t might be, but it never has been, the law that a person is only entitled to enforce his contractual rights in a reasonable way, and that a court will not support an attempt to enforce them in an unreasonable way.'101

It is beyond the purpose of this dissertation to challenge such widely disseminated views, however tempting that may be. Moreover, it is my belief that in the White \& Carter case Lord Reid has totally missed the point. And so have those who trust the answer to this problem to lie in the principle of good faith. Indeed, the good faith line of reasoning has essentially been used to counter the statement that a party can exercise his contractual rights for any reason or no reason at all. However, in order to discuss how one should and should not exercise one's contractual rights, it is necessary to establish which contractual rights one does have in the first place. In the situation under analysis, the

Conferenze e Seminari 2, Rome 1992); the several papers arising from the Fourth Annual Conference of the JCL on 'Good faith and fairness in commercial contract law' published in (1994) 7 JCL and (1995) 8 JCL; JN Adams and R Brownsword Key Issues in Contract (Butterworths London 1995) Ch 7; R Brownsword " "Good faith in contracts" revisited' (1996) 49 CLP 111; J Beatson and D Friedmann (edd) Good Faith and Fault in Contract Law (OUP Oxford 1997); R Harrison Good Faith in Sales (Sweet and Maxwell London 1997); G Teubner 'Legal irritants: good faith in British law or how unifying law ends up in new divergencies' (1998) 61 MLR 11; ADM Forte (ed) Good Faith in Contract and Property (Hart Publishing Oxford 1999); R Brownsword, NJ Hird and G Howells (edd) Good Faith in Contract: Concept and Context (Dartmouth Publishing Co Aldershot 1999); O Lando and H Beale Principles of European Contract Law (Kluwer Law International The Hague London Boston 2000) 113-9; R Zimmermann and S Whittaker (edd) Good Faith in European Contract Law (CUP Cambridge 2000).

100 Chapman $v$ Honig [1963] 2 QB 502 (CA) 520 (Pearson LJ), Lord Denning MR dissenting. See also Jones $v$ Swansea CC [1990] 1 WLR 54 (CA), reversed on the facts but not on the law in [1990] 1 WLR 1453 (HL).

101 [1962] AC 413 (HL) 430. See, however, Gator Shipping Corp v Trans-Asiatic Oil Ltd SA (The Odenfeld) [1978] 2 Lloyd's Rep 357, 373 and Clea Shipping Corp v Bulk Oil International (The Alaskan Trader) (No 2) [1984] 1 All ER 129, 136-137 for the proposition that a party will not be allowed to recover the full contract price whenever his behaviour in keeping the contract alive was 'wholly unreasonable' and therefore against general equitable principles. And see Staughton LJ's remarks in Stocznia Gdanska SA v Latvian Shipping Co [1996] 2 Lloyd's Rep 132 (CA) 138-139, which can be said to amount to an acknowledgment of the requirement of good faith in contractual performance. See 56-57 below. 
NO RIGHT TO PERFORM A CONTRACT?

question that should therefore have been asked is: does $P$ have the right to perform his part of the contract?

\section{YET ANOTHER HIDDEN ASSUMPTION}

In the classic anticipatory breach situation, the party who expresses his intention not to perform his part of the contract is clearly in breach of contract (whether it be an operative or an inoperative breach of contract ${ }^{102}$ ). Nonetheless, in those cases where P's performance is supposed to precede R's, it seems perfectly plausible for one to anticipate that $R$ might on occasion wish to prevent $\mathrm{P}$ from performing his part of the contract without at the same time trying to terminate the whole contract in order to duck out of his own contractual duties in the process. What if, rather than refusing to perform his own part of the contract, $\mathrm{R}$ merely expresses the wish not to endure P's performance? What if, rather than an invitation to rescind, his words or conduct merely spell out a desire to reject the benefit of the contract, a determination to renounce his right to demand the other party's services whilst keeping the contract alive? Why do the courts always assume that whenever someone expresses a wish that something not be done, that behaviour must be regarded as repudiatory?

So far the courts have indiscriminatingly characterised every attempt on R's part to hinder P's performance as a straightforward case of repudiation, which is to say as an actual or potential breach of contract - a civil wrong. They have never taken any time to consider the possibility that in some cases it might make sense for them to recognise R's right to decide not to accept the benefit of the contract. Accordingly, no matter how objectionable P's conduct might in any given case have been, the courts have obstinately treated him as 'the innocent party', leaving poor $\mathrm{R}$ no choice but to play the role of the villain - the wrongdoer. ${ }^{103}$ Such is the effect of yet another of their hidden assumptions.

102 The idea that the repudiation only becomes an operative breach of contract once the other party has accepted it has generally had the acceptance of the courts, despite its flagrant technical shortcomings. See Tredegar Iron \& Coal Co v Hawthorn Bros \& Co (1902) 18 TLR 716 (CA) 716; Heyman v Darwins [1942] AC 356 (HL) 382.

103 For two very enlightening examples of the sort of behaviour I am alluding to see Rockingham County v Luten Bridge (1929) 35 F 2d 301, where a bridge was erected in the midst of a forest, and Clea Shipping Corp v Bulk Oil International (The Alaskan Trader) (No 2) [1984] 1 All ER 129, where a ship was senselessly repaired and then kept fully crewed and ready to sail for the duration of the charter. 


\section{Margarida LIMA Rego}

At this stage, it is only fair to concede that whenever $\mathrm{R}$ has lost all interest in P's performance he will be much more likely to repudiate the contract than to try and stop P from performing whilst keeping the contract alive. However, my point is that up to the present the courts' obsession with the unlawful aspects of R's behaviour has kept them from looking elsewhere in search of alternative approaches to the problem under consideration even in those cases where the wrongfulness of such behaviour was beyond dispute.

In other words, even where the courts' assumption as to the wrongfulness of R's conduct happens to be correct, that does not mean they should be compelled to ignore his averred loss of interest in P's performance. That is, just because $\mathrm{R}$ cannot be allowed to terminate the contract without P's assent it does not automatically follow that his conduct should be wholly devoid of effect. Generally speaking, as well as attempting to terminate the contract $\mathrm{R}$ will also be letting $\mathrm{P}$ know that he has lost all interest in the services he is about to provide. Those two aspects of one and the same conduct are different and should therefore be dealt with separately. As to the latter - P's awareness of the uselessness of his own future performance -, its relevance should depend on the answer to a single question: does $\mathrm{P}$ have the right to perform his part of the contract?

\section{E. THE RIGHT TO RENOUNCE THE BENEFIT OF A CONTRACT}

Earlier on in this dissertation it was submitted that P's right to perform his own part of the contract should not be universally predetermined, for its existence should rather depend on the precise circumstances of the case before the court, and on the proper construction of the contract under scrutiny. Once this submission has been accepted, it should then follow that, whenever one reaches the conclusion that in any given case $\mathrm{P}$ has not in fact secured such a right, he should not be allowed to wholly disregard R's professed loss of interest in the services he is about to supply only because he happens to be able to render them without R's cooperation.

Indeed, should $\mathrm{R}$ be recognised the opportunity to bargain for a right to reject P's performance, it is only logical that he should be allowed to do so regardless of whether he is actually able to prevent $\mathrm{P}$ from performing by withdrawing his cooperation. At this stage one begins to realise that the whole affair of cooperation and the lack thereof is in fact quite incidental to the problem under analysis. Should one accept that in any given case it is possible for $\mathrm{R}$ to have secured the discretionary power to release $\mathrm{P}$ from his duty to supply his services by refusing to cooperate, and for $\mathrm{P}$ to have agreed to be under the 
correlative liability to have $\mathrm{R}$ thus wipe out his duty at will, there is absolutely no reason not to accept that R's position must be equally protected in those cases where for some reason his cooperation is not required.

To put it more clearly, whenever $\mathrm{R}$ has secured for himself the right to reject $P$ 's performance $P$ has conversely relinquished the right to perform his own part of the contract. The two rights are irreconcilable, in that they are diametrically opposed. The question that should then be asked, as a simple matter of construction, is as follows: upon entering the contract, has $\mathrm{R}$ sacrificed his control over the decision whether to get the benefit of the contract?

This aspect of contracting has so far been kept pretty obscure. One should not, however, underestimate the importance of retaining some control over the outcome of the contractual enterprise at every step of the way. For instance, a soap manufacturer who contracts with an advertising agency to advertise a soon-to-be-released soap but later discovers one of its components to be momentarily out of stock, which forces him to postpone its release, would be more than willing to prevent the agency from displaying their adverts all over the country. But would he have secured the power to do so at the contracting stage?

Ultimately, therefore, it all comes down to a single question: does $\mathrm{P}$ have the right to perform his own part of the contract? The parties to a contract will usually not have expressly discussed this matter. Hence when construing the contract one must look for what has remained unsaid. One should always bear in mind that there are at least two sides to every bargain, and that as a result there is no necessary correlation between a duty to perform and a right to perform. Indeed, in the vast majority of cases $\mathrm{P}$ would have absolutely no direct interest in actually performing his part of the contract. ${ }^{104}$ Such correlation would only make sense reflexively, that is, in order to secure a right to the counter-performance. Once disentangled that link, ${ }^{105}$ however, there is no reason to recognise such a right - unless, of course, P's actual performance is part of the agreed consideration, as in the leading actor example. ${ }^{106}$ In all other cases it would be pointless for $\mathrm{P}$ to be recognised the right to perform his part of the contract.

It is therefore submitted that, unless a court is satisfied that a right to perform was effectively part of the bargain under scrutiny, $R$ should be recogni-

104 See ML Pereira Conceito de Prestação e Destino da Contraprestação (Almedina Coimbra 2001) 222-223.

105 See 41-42 above for the submission that in most cases should $\mathrm{R}$ fail to cooperate he will still be liable for the full contract price, inasmuch as $\mathrm{P}$ did not take upon himself the risk of such lack of cooperation.

106 See 39 above. 
sed both the right to renounce the benefit of the contract and the corresponding power to prevent $P$ from performing merely by giving him due notice of his loss of interest. ${ }^{107}$ This is the only solution that effectively protects R's best interests in all those cases where no cooperation on his part is needed in order for $\mathrm{P}$ to perform, in that it fully acknowledges the significance of retaining some control over the benefit of a bargain after it has been agreed upon. But it would obviously apply to every factual situation regardless of whether R's cooperation would or would not be required in order for $\mathrm{P}$ to perform his part of the contract.

\section{F. PREVENTION BY NOTIFICATION}

Indeed, should R's right to renounce the benefit of the contract be accepted by the courts, it should logically follow that, in any given factual situation, once $\mathrm{R}$ has effectively exercised such a right by duly notifying $\mathrm{P}$ of his decision not to accept his services the latter will immediately cease to be capable of performing his part of the contract as it originally stood. This will be so regardless of whether he is physically able to supply his services without R's cooperation, ${ }^{108}$ for R's power to prevent P's performance operates on a purely conceptual basis. That is to say, once the renunciation has taken place, 'performance' of that particular contractual promise will automatically cease to be possible, insofar as, whichever course of action $P$ decides to take - most particularly whether or not he chooses to do the thing which is the subject-matter of that promise - his conduct will no longer be susceptible of being characterised as that promise's performance.

Such is R's power to prevent $P$ from performing his part of the contract - it does not entitle nor require him to physically stop $\mathrm{P}$ from rendering his services, it rather operates by conceptually doing away with P's ability to

107 On prevention by words see Cort and Gee v The Ambergate (1851) 17 QB 127. ' $[\mathrm{M}]$ ay I not reasonably say that I was prevented from completing a contract by being desired not to complete it? Are there no means of preventing an act from being done, except physical force or brute violence?' Same case 145 (Lord Campbell CJ).

${ }_{108}$ This line of argument is just as valid when it comes to those cases where $P$ cannot perform due to R's lack of cooperation where, even before that cooperation is lacking, $\mathrm{R}$ may inform $\mathrm{P}$ that he is no longer interested in his services, thereby ensuring that any future action on P's part will not be characterised as directed towards performance, and consequently will not be considered when it comes to calculating P's expenses. That notice alone should be enough to successfully prevent any further 'performance' of the contract on P's part. 
NO RIGHT TO PERFORM A CONTRACT?

'perform'. As of the moment the right to renounce the benefit of the contract is exercised, performance of the contractual promise in question simply becomes legally impossible. Hence even in those cases where $\mathrm{R}$ cannot physically prevent P's supply of services he will still be able to prevent him from legally 'performing' his part of the contract - though this does not mean that the contract has come to an end. Needless to say, after exercising his right of renunciation $\mathrm{R}$ will prima facie still be liable for the full contract price.

In those cases where $\mathrm{R}$ has decided to renounce the benefit of the contract merely because he has lost all interest in P's services and wishes to prevent the latter from incurring any further redundant expense on the contract, his position will be fully protected by the suggested conceptual solution. Whichever course of action $\mathrm{P}$ chooses to take, his expenditure will as of that moment cease to be connected to that particular contract, thus shall not be taken into consideration in any subsequent calculation of P's contractual expenses.

Nonetheless, because R's powers of prevention are of a purely conceptual nature and so do not interfere with P's chosen course of (physical) action, in all those cases where $P$ can effectually render his services without R's cooperation there is still one issue in need of attention: whenever R's decision to renounce the benefit of the contract stems from his fear that the object of P's performance may turn out to be a nuisance or even injure his own best interest he will be in definite need of further protection. ${ }^{109}$ When this be the case, should $\mathrm{P}$ choose to disregard R's renunciation and go ahead with 'performance' against R's will the latter must at the very least be allowed to ask the courts for an injunction. And there is certainly room for the view that P's behaviour - should he choose to 'perform' - might properly be deemed unlawful. ${ }^{110}$ However, the length of this dissertation does not allow me to elaborate any further on this matter.

109 Take the case of the soap example (see 51 above).

110 Should an injunction not be granted in due time, he would then be held liable for whichever harm $\mathrm{R}$ may come to suffer as a direct result of P's actions. P's conduct might be characterised as a breach of contract. Alternatively, P might be held liable for a breach of his duty of care towards R. Ultimately, P might be held liable for performing even in those cases where $\mathrm{R}$ has not yet had a chance to actively and properly renounce the benefit of the contract. His awareness of the damaging potential of his future performance should suffice, at least as far as the tort of negligence is concerned. It should be noted, however, that as my position currently stands $\mathrm{P}$ is only required to take notice of R's will - once expressed - not of his best interest. 


\section{G. 'NO LEGITIMATE INTEREST, FINANCIAL OR OTHERWISE'}

At this stage it might be useful to take a closer look at a certain passage from Lord Reid's judgment in the White \& Carter case in which he hints at what has later become known as the legitimate interest qualification to the innocent party's right to perform. Indeed, one of the premises on which my thesis is grounded is the submission that in a large number of cases $P$ will have no interest in actually performing his part of the contract other than that of reflexively securing his right to the full contract price. And yet, when dealing with this qualification, both judges and academics seem to share the view that only in the rarest and most peculiar of cases will the innocent party have absolutely no legitimate interest in performing the contract. ${ }^{111}$ In fact, in this country such an allegation has only been successfully pleaded, as reported, in a couple of shipping cases. ${ }^{112}$ This is indeed a startling state of affairs, for one would think that the sort of questions that would be asked in order to determine whether $\mathrm{P}$ has a legitimate interest in performing cannot greatly differ from the ones that $I$ have been putting forward as a means of finding out whether P should be recognised the right to perform in the first place. ${ }^{113}$ A careful analysis of their arguments seems to be in order.

It may well be that, if it can be shown that a person has no legitimate interest, financial or otherwise, in performing the contract rather than claiming damages, he ought not to be allowed to saddle the other party with an additional burden with no benefit to himself. ... [H] ought not to be allowed to penalise the other party by taking one course when another is equally advantageous to him. ${ }^{114}$

Such were Lord Reid's observations in the White \& Carter case, which several commentators have fittingly described as being uncharacteristically vague and imprecise. ${ }^{115}$ Nonetheless, Lord Reid appears to sustain the view that even

${ }_{111}$ See Gator Shipping Corp v Trans-Asiatic Oil Ltd SA (The Odenfeld) [1978] 2 Lloyd's Rep 357, 374 and Clea Shipping Corp v Bulk Oil International (The Alaskan Trader) (No 2) [1984] 1 All ER 129, 137.

112 See Attica Sea Carriers Corp v Ferrostaal Poseidon Bulk Rederei (The Puerto Buitrago) [1976] 1 Lloyd's Rep 250 (CA) and Clea Shipping Corp v Bulk Oil International Ltd (The Alaskan Trader) (No 2) [1984] 1 All ER 129.

113 Except that I have clearly stated this to be a matter of construction - hence one that belongs in the chapter of the formation of contracts - whereas it could be argued that a 'legitimate interest' of the sort alluded to by Lord Reid might well be shaped at a later stage of the events.

114 White \& Carter (Councils) Ltd v McGregor [1962] AC 413 (HL) 431.

115 See JW Carter, A Phang and SY Phang 'Performance following repudiation: legal and economic interests' (1999) 15 JCL 97, 107-116; LJ Priestley 'Conduct after 
though in principle $\mathrm{P}$ must be allowed to perform his own part of the contract whenever he can do so without R's cooperation his right to perform ${ }^{116}$ must give way whenever the following two requisites are met: (i) $\mathrm{P}$ must have no 'legitimate interest' in performing his part of the contract, whatever that means; and (ii) there must be at least some disparity between the scale of any advantages that $\mathrm{P}$ might derive from performing (which logically do not amount to a legitimate interest) and that of the hardship which would be inflicted upon $\mathrm{R}$ should he be forced to endure such performance.

Nowhere in his judgment does Lord Reid explain the concept of legitimate interest. In fact, the only conclusion that can safely be drawn from his lordship's own words is that he must have meant to refer to the absence of any legitimate interest other than his interest in claiming the contract price rather than damages for breach of contract. Nonetheless, and even though such a concept has with one exception ${ }^{117}$ just about monopolised the attention of every judge and academic who has ever come across Lord Reid's statement, it is my belief that the key element of his proposition is the latter of those two requirements - namely the existence of some disparity between the relative weight of the parties' claims to performance (or non-performance, as the case may be) - insofar as, at the end of the day, that disparity has revealed itself to be the decisive factor in the bulk of the cases that so far have come before the English courts.

Indeed, if one takes into consideration those rare cases where P's claim to the full contract price was not allowed, one is immediately stricken by the realisation that what those factual situations have in common - which has predominantly tempted the courts into accepting R's contention that he is not

breach: the position of the party not in breach' (1990-91) 3 JCL 218, 225; PM Nienaber 'The effect of anticipatory repudiation: principle and policy' [1962] CLJ 213, 231; MP Furmston 'The case of the insistent performer' (1962) 25 MLR 364, 367; 'The rule in White \& Carter (Councils) Ltd v McGregor' - a report by the Contracts and Commercial Law Reform Committee, presented to the New Zealander Minister of Justice on 5 May 1983 (New Zealand Law Society) 13. See also Decro-Wall International SA $v$ Practitioners in Marketing [1971] 1 WLR 361 (CA) 370, where the very existence of the so-called legitimate interest qualification was seriously doubted.

116 Either his right to perform or, should one follow an alternative interpretation of his lordship's words, the range of remedies at his disposal. See Decro-Wall International SA v Practitioners in Marketing [1971] 1 WLR 361 (CA) 375; Hill v CA Parsons \& Co [1972] 1 Ch 305 (CA); Clea Shipping Corp v Bulk Oil International (The Alaskan Trader) (No 2) [1984] 1 All ER 129, 137.

117 That of economic waste. See PM Nienaber 'The effect of anticipatory repudiation: principle and policy' [1962] CLJ 213, 227, 231; JW Carter Breach of Contract (2nd edn Sweet \& Maxwell London 1991) \$1128. 
liable for the full contract price - is the fact that P's conduct has given rise to an outrageous instance of economic loss, as well as amounting to a pure waste of time and resources whenever the end result is something which is of no value to anybody. ${ }^{118}$ In the White \& Carter case, on the other hand, not only was the respondents' loss not that impressive, the waste issue was also not that obvious either. ${ }^{119}$ What separates these cases from each other is therefore not so much the legitimacy of P's interest in performing - which was fairly equivalent in all the cases - but rather the magnitude of the loss he would be inflicting on $\mathrm{R}$ should he be made to pay him the full contract price, as well as the corresponding waste of resources such performance amounts to. ${ }^{120}$ In other words, and despite what the courts have been saying, in any given case the final decision will pretty much hinge on the strength of R's (or society's) claims to non-performance - not on the illegitimacy of P's interest in performing.

I believe this element of Lord Reid's proposition can safely be said to be very closely related to the requirement of good faith in the performance of

118 Hence in Clea Shipping Corp v Bulk Oil International (The Alaskan Trader) (No 2) [1984] 1 All ER 129 a ship chartered to the defendants for a period of approximately two years was returned to the claimants in repudiation of the time charter at the end of the first year because it was in need of extensive repairs. The latter nevertheless chose to repair the ship and keep it fully crewed and ready to sail throughout the remainder of the stipulated time. And in Attica Sea Carriers Corp $v$ Ferrostaal Poseidon Bulk Rederei (The Puerto Buitrago) [1976] 1 Lloyd's Rep 250 (CA), another shipping case (whose factual situation did not, however, rigorously speaking, raise any of the problems that concern this dissertation), where the charterers of a ship returned it without the requisite repairs because they would have cost more than the repaired ship would have been worth. See also Lord Keith's Hong Kong expert example in the White and Carter case (at 442). For an equally impressive American case, see Rockingham County v Luten Bridge (1929) 35 F 2d 301 (see n 103 above).

119 See AL Diamond 'Commerce, customers and contracts' (1978) 11 MelULRev 563, 574-6 for the submission that the appellants in the White \& Carter case did not inflate their loss by performing rather than accepting the respondents' repudiation and claiming damages inasmuch as they were 'lost volume sellers' and could not therefore have relet the space to any other client. See 65 below.

120 A more communitarian approach would lay more stress on the waste factor, whereas a more individualistic approach such as my own would tend to highlight the loss factor. Note that, should one's major goal be the avoidance of waste, the solution to the problem under analysis must vary according to whether the contract is still wholly executory, partly executory or wholly executed. If one's main concern is the rejection of unwanted services, however, it should not make much difference what stage of the process one happens to be at. 
contracts ${ }^{121-122}$ - an aspect which has since been reinforced by Staughton LJ's unambiguous statement in Stocznia Gdanska SA v Latvian Shipping $\mathrm{Co}^{123}$ that 'the innocent party must have reasonable grounds for keeping the contract open bearing in mind also the interests of the wrongdoer.'124 However, as has been previously pointed out, the whole of this approach is built on the assumption that there is a right to perform which is susceptible of being abused.

Thus we are back to where we started from, that is, the question whether $P$ has a right to perform his own part of the contract. For only where he does would it make sense for one to question the legitimacy of its exercise under the circumstances of the case before the court. In order for Lord Reid's qualification to be of any use here, one should then focus on P's supposed legitimate interests in performing, rather than at R's - or society's - interests in hindering his performance. As for the former, the one interest that has frequently been brought to the attention of the courts is that of the difficulty of assessing damages - or of their adequacy - should P relinquish his claim to the full con-

121 How this approach can properly be reconciled with Lord Reid's earlier disapproval of the suggestion that a person must exercise his contractual rights in a reasonable way (see 47-48 above) is a somewhat delicate question. Later attempts at such reconciliation appear to have settled on the adoption of a distinction between what constitutes 'unreasonable behaviour' and 'wholly unreasonable behaviour'. See Gator Shipping Corp v Trans-Asiatic Oil Ltd SA (The Odenfeld) [1978] 2 Lloyd's Rep 357, 373 and Clea Shipping Corp v Bulk Oil International (The Alaskan Trader) (No 2) [1984] 1 All ER 129, 136-137.

122 In fact Lord Reid's observations strongly resemble one particular instance of the German doctrine of the inadmissible exercise of legal rights (die unzulässige Rechtsausübung). See K Larenz and M Wolf Allgemeiner Teil des bürgerlichen Rechts (8th edn CH Beck Munich 1997) 322-330. 'Ein berechtigtes Eigeninteresse fehlt auch bei geringfügiger Interessenbeeinträchtigung, wenn durch die Rechtsausübung anderen unverhältnismäßige Nachteile entstehen.' Same book 328 ('A legitimate interest is also lacking whenever the negligible benefits one would derive from the exercise of a right are disproportionately outweighed by the serious disadvantages its exercise would inflict in others.'). See also AM Cordeiro Da Boa Fé no Direito Civil (reprint Almedina Coimbra 1997) 853.

123 [1996] 2 Lloyd's Rep 132 (CA).

124 Same case 139. Lord Reid's dictum has also been applied or approved in Attica Sea Carriers Corp v Ferrostaal Poseidon Bulk Rederei (The Puerto Buitrago) [1976] 1 Lloyd's Rep 250 (CA); Gator Shipping Corp v Trans-Asiatic Oil Ltd SA (The Odenfeld) [1978] 2 Lloyd's Rep 357; and Clea Shipping Corp v Bulk Oil International (The Alaskan Trader) (No 2) [1984] 1 All ER 129, where it was said - again using language which is strongly evocative of good faith - that 'there comes a point at which the Court will cease, on general equitable principles, to allow the innocent party to enforce his contract according to its strict legal terms' (at 136). 
tract price. ${ }^{125}$ That argument, however, does not apply because the present study supports the recognition of P's right to claim the full contract price.

A few of the cases support the view that P's interest in performing will be deemed legitimate whenever he has entered into commitments with third parties which he must honour as a matter of business. ${ }^{126}$ It has further been argued, in a somewhat connected way, that the interest in protecting one's own reputation should be considered a legitimate one. ${ }^{127}$ But these submissions seem here somewhat misplaced, given that they deal with a situation where $\mathrm{P}$ has already relied on the contract - whether by taking some steps towards performance or simply by making further engagements on the supposition that the contract would be completed - something which brings forth an entirely different set of issues which cannot possibly be appropriately handled in the context of a study that is mostly concerned with the proper construction of a contract and which therefore must focus on the contract itself and the circumstances that surround its inception, rather than on what takes place afterwards.

As far as the protection of one's own reputation is concerned, however, whenever the problem derives from the fact that $\mathrm{P}$ will no longer be able to enhance it amongst his peers by performing his part of the contract - such as in the leading actor type of case ${ }^{128}$ - then either performance of that particular task is actually part of the consideration (as in the example only just mentioned) or it should not be taken into consideration at all, for such an enhancement was something which had not been bargained for at the time of contracting. It could also be a matter of the particular way in which $\mathrm{R}$ exercises his right to reject performance - which can surely be exercised in an unconscionable way, insofar as the right to renounce the benefit of the contract is surely as susceptible of being abused as any.

125 See Gator Shipping Corp v Trans-Asiatic Oil Ltd SA (The Odenfeld) [1978] 2 Lloyd's Rep 357, 374. See also George Barker (Transport) Ltd v Eynon [1974] 1 WLR 462 (CA) and Attica Sea Carriers Corp v Ferrostaal Poseidon Bulk Rederei (The Puerto Buitrago) [1976] 1 Lloyd's Rep 250 (CA) 255-256. See GH Treitel The Law of Contract (10th edn Sweet \& Maxwell London 1999) 946.

126 See Anglo-African Shipping v J Mortner [1962] 1 Lloyd's Rep 81, 94 (affirmed on other grounds at 610 ), where the example of an innocent party who had entered into various sub-contracts - such as taking shipping space in order to ship the goods to their agreed destination - for the purpose of performing his contract was given; and Gator Shipping Corp v Trans-Asiatic Oil Ltd SA (The Odenfeld) [1978] 2 Lloyd's Rep 357,374 , where the shipowners had assigned to a third party hire due under the charterparty.

127 See above $n$ 126. See the arguments of counsel for the claimants in the White \& Carter case (at 418, 420, 425).

128 See 39 above. 
In the end, therefore, I reiterate my initial submission that in a significant number of cases $\mathrm{P}$ will not have any direct interest in performing his part of the contract, given that whichever advantages he might derive from performance quite simply were not part of the bargain. $R$ must not be held liable for the entire chain of events that completion of that contract would set in motion. ${ }^{129} \mathrm{He}$ should only have to answer for those events for whose occurrence he has in some way accepted responsibility. All things considered this is, once again, a matter of risk-allocation and of the proper construction of each individual contract.

\section{CHAPTER IV}

\section{DEDUCTING FROM THE FULL CONTRACT PRICE}

\section{A. THE NEED FOR A DEDUCTION}

The situation of the contractual party who loses all interest in the other party's performance and accordingly decides to reject the benefit of the contract is in serious need of a separate and independent legal solution. Our starting point is that the contract is still in force, and that since the risk of R's loss of interest is borne entirely by him he is still prima facie liable for the full contract price. ${ }^{130}$ As a result $P$ has at his disposal an action in debt - a claim ex contractu which (it is settled law) does not presuppose a breach of contract in its inception. ${ }^{131}$ Nonetheless, it is my belief that in this situation $\mathrm{R}$ should not be made to pay the full contract price. He should be allowed to deduct from the contract price whichever sums $P$ has saved or otherwise made as a consequence of his release from the duty to perform his part of the contract.

129 Somewhat in support of this statement, albeit in the context of determining the right measure of expectation damages, see the recent decision of the House of Lords in South Australia Asset Management Corp v York Montague [1997] AC 191 which introduced the technique of defining the boundaries of contractual liability by means of a rigorous construction of the scope of the duties each party has undertaken upon entering the contract, that is to say, by a thorough analysis of the risks that have been assumed by each of the parties as part of their bargain.

130 Compare K Larenz Lehrbuch des Schuldrechts I (14 edn CH Beck'sche Verlagsbuchhandlung Munich 1987) 399-402; RL Faria A mora do credor (Lex Lisboa 2000) 32-38. Guilt is not at stake here, given that the discharge is simply attributed to the promisee as the person whose lawful conduct was responsible for its event.

13] See Marks v Lilley [1959] 1 WLR 749. 
In the first place, making $\mathrm{R}$ pay for the full contract price would be an extremely inefficient solution. Whenever P's performance can actually be damaging to R's interest the question does not arise, for as has been said before under these circumstances $R$ should be allowed to ask the courts for an injunction. ${ }^{132}$ In every other case, however, if one allows $P$ to go ahead and physically supply his unwanted services to $\mathrm{R}$ - despite them not being characterised as performance of the contract - this will amount to a senseless squander of both human and material resources, to a pure waste of time and money. Thinking in terms of efficiency only, in order to persuade P not to go ahead and supply his services to $\mathrm{R}$ one should try to find a way of promoting the most rational behaviour by both contractual parties, that is, one should endeavour to come up with a solution that encourages both P's inactivity and R's early notice of his loss of interest - his early renunciation. The only way of doing that is by providing $\mathrm{R}$ with a financial incentive to renunciation: everything that $\mathrm{P}$ saves through his inactivity $\mathrm{R}$ is allowed to deduct from the full contract price.

Moreover, one should take into account the general policy against overcompensation. Indeed, even though P's right to the full contract price consists in his primary contractual right to the agreed counter-performance ${ }^{133}$, the context in which this right is being asserted is functionally different from the original one. That is, with payment of the price one is aiming at putting $\mathrm{P}$ in the position he would have been in had he duly supplied his services to $R$, rather than at rewarding him for the actual performance of those services. ${ }^{134}$ There is no fiction of performance in this solution, there is rather the purpose of compensating $\mathrm{P}$ from his non-performance - hence the deduction.

In a few words, even though $P$ is still recognised the right to the counterperformance, insofar as the contract is still in force, that right is performing a compensatory function now. So the principle of indemnity and the policy against over-compensation come into play. As a result, the expectation measure of damages becomes relevant, though purely as an upper limit, because $P$ should not end up being better off than he would have been had he duly performed his part of the contract. ${ }^{135}$ Hence P's right to the contract price must

132 See 53 above.

133 See Lord Diplock's explanation of the difference between primary and secondary obligations in Photo Production Ltd v Securicor Transport [1980] AC 827 (HL).

134 Compare MLPereira Conceito de Prestação e Destino da Contraprestação (Almedina Coimbra 2001) 234.

135 This policy against over-compensation can be said to derive from a principle of unjust enrichment by prevention, whatever its usefulness may be. In Banque Finan- 
NO RIGHT TO PERFORM A CONTRACT?

be curtailed in order to give effect to such a policy. Everything that he has in fact saved through his non-performance must be taken into account and deducted from the full amount he would have received had he duly performed his part of the contract.

\section{B. HOW TO DEDUCT: MITIGATION}

At this point the doctrine of mitigation can properly be reintroduced. Why exactly did the mitigation rules not apply in an action in debt? It is commonly said that they do not apply because there was no breach of contract. ${ }^{136}$ This criterion may, generally speaking, work relatively well as a rule of thumb. And in the standard case it is indisputably the breach that effectively triggers the application of those rules. However, the absence of a breach of contract is, in itself, wholly irrelevant to this problem. The significant factor is the non-compensatory nature of the available remedy. Indeed, what prevents the mitigation rules from being applied here is the fact that an action in debt is aimed at enforcing the defendant's primary contractual obligations, rather

cière de la Cité v Parc (Battersea) [1999] AC 221 (HL), 'Lord Hoffmann proposed a framework under which the principle of unjust enrichment is the basis of two species of right: first, rights which operate to reverse unjust enrichment; and secondly, rights which prevent or pre-empt an unjust enrichment.' $\mathrm{R}$ Williams 'Preventing unjust enrichment' [2000] RLR 492, 492. Lord Hoffmann's speech is consistent with the view that the principle of unjust enrichment may generate remedies other than restitution. By way of illustration, one could think of the decision in Inchbald $v$ Western Neilgherry Coffee, etc, Co (1864) 17 CB (NS) 733. To the extent that there is evidence of a principle of indemnity in English law, that principle would appear to be given effect by a simple reduction of the claimant's damages. There are dicta to the effect that it also applies to damages for breach of contract. See Hopkins $v$ Norcros Plc [1993] ICR 11 (CA) 14 (Staughton LJ). See same article 504; A Burrows The Law of Restitution (Butterworths London 1993) 80 and Understanding the Law of Obligations:. Essays on Contract, Tort and Restitution (Hart Publishing Oxford 1998) 188; C Mitchell 'Subrogation, unjust enrichment and remedial flexibility' [1998] RLR 144, text to $n$ 9; S Degeling 'Carer's claims: unjust enrichment and tort' [2000] RLR $172,185-187$.

136 See Shindler v Northern Raincoat Ltd [1960] 1 WLR 1038, 1048; Brown v Muller (1872) LR 7 Exch 319; Tredegar Iron \& Coal Co v Hawthorn Bros \& Co (1902) 18 TLR 716 (CA). See WED Davies 'Anticipatory breach and mitigation of damages' (1960-62) 5 UWAusLRev 576, 690; E Tabachnik 'Anticipatory breach of contract' [1972] 25 CLP 149, 164; F Dawson 'Metaphors and anticipatory breach of contract' [1981] CLJ 83, 105. 
than at compensating the claimant for the loss he suffered as a result of the defendant's non-performance. ${ }^{137}$

To be sure, mitigation is mitigation of loss. Whenever the concept of loss is irrelevant, what is there to mitigate? In this case, however, even though there was no breach of contract proper, there is definitely an element of compensation in the claimant's remedy. As said before, the award of the contract price is aimed at putting $\mathrm{P}$ in the position he would have been in had he duly supplied his services to $\mathrm{R}$, rather than at rewarding him for the actual performance of those services. Therefore, the expectation measure becomes relevant, and so does the concept of loss (or the lack thereof). Moreover, given that there was no breach of contract, R's interest deserves even more protection than a wrongdoer's; it would make absolutely no sense to limit an award of damages for breach of contract by resorting to the rules of mitigation and not being able to do the same in the case of someone whose conduct was in every aspect perfectly lawful.

Since the general idea is that $\mathrm{P}$ should not end up being better off than he would have been had he duly rendered his services to $R$, one must compare the position he would have occupied had performance taken place with the position he would been in should he be awarded the full contract price. In other words, one must determine exactly how much he has saved and how much he has otherwise profited from his inactivity in order to deduct that sum from the full contract price, so as not to leave $\mathrm{P}$ in a better position than he would have occupied had he duly performed his part of the contract.

At the outset, we are dealing here with the concept of mitigation in fact. There is here no question of a 'duty' to behave reasonably, since what matters is how much $\mathrm{P}$ has in fact saved by non-performing. However, should $\mathrm{P}$ not have behaved reasonably, should he have gone ahead and supplied his services to $R$, whatever he failed to save must not be taken into account - it must not be characterised as constituting an expense in any way related to performance of his contractual obligations. ${ }^{138}$ By way of illustration, should the contract have been for the supply of a kitchen table, if $\mathrm{P}$ went ahead and effectively built a kitchen table, that fact must be deemed wholly irrelevant; legally he must be deemed to have saved the expense of building a kitchen table for the perfor-

137 See British Westinghouse Electric and Manufacturing Co v Underground Electric Rlys of London [1912] AC 673 (HL) 689; Jamal (AKAS) v Moolla Dawood, Sons \& Co [1916] 1 AC 175 (PC) 179; Banco de Portugal $v$ Waterlow and Sons [1932] AC 452 (HL); Dunkirk Colliery Co v Lever [1878] 9 Ch Div 20 (CA).

138 See $\mathrm{n} 110$ above as to $\mathrm{P}^{\prime}$ s potential liability in damages towards $\mathrm{R}$, both in contract and in tort. 
mance of that contract. Hence he shall have to bear that loss himself. Additionally, the value of the table he has ended up with or the profit he makes out of selling it should be taken into account as alternative profits directly flowing from his release.

Does this amount to a burden to mitigate? Actually, all that $\mathrm{P}$ does after R's notification simply cannot be characterised as performance, so we do not count it as an expense that related to performing the contract. However, one could say that the concept of burden also applies here. $\mathrm{R}$ has notified $\mathrm{P}$ of his loss of interest in his services, and thereby he has given him the opportunity of avoiding any (further) detriment to himself. The choice is therefore his to decide whether to take this opportunity or not, assuming this is not one of those cases where 'performance' has become unlawful. Should he choose to 'perform', he must bear the expenses himself. Seen in this light, this does amount to a burden to mitigate loss.

\section{THE WAY TO DO IT: TRANSACTION SET-OFF}

The technical device of set-off is the best way to deduct from the full contract price both the amount of money $\mathrm{P}$ has saved and what he has otherwise profited from his inactivity. I shall resort to the terminology adopted by Wood in his work ${ }^{139}$ and call the device here discussed transaction set-off. According to this author, transaction set-off may be resorted to whenever reciprocal claims arise out of the same or a closely connected transaction, and includes both abatement and equitable set-off. ${ }^{140}$ Although the distinction between both these forms of transaction set-off has received sanction from the House of Lords, the differences between them are increasingly slight ${ }^{141}$, therefore I shall henceforth limit myself to the broader concept without distinguishing which of the two specific devices I am referring to.

139 PR Wood English and International Set-off (Sweet \& Maxwell London 1989). For a thorough explanation of the concept of transaction set-off see the aforementioned book, particularly No 4 .

140 As to abatement, see Aries Tanker Corp v Total Transport Ltd [1977] 1 WLR 185 (HL) and Gilbert Ash (Northern) Ltd v Modern Engineering (Bristol) Ltd [1974] AC 689 (HL). This device is traditionally restricted to contracts for the sale of goods or for work or labour. As to equitable set-off see Hanak v Green [1958] 2 QB 9 (CA) and British Anzani (Felixstowe) Ltd $v$ International Marine Management (UK) Ltd [1980] 1 QB 137.

141 See PR Wood English and International Set-off (Sweet \& Maxwell London 1989) 117. 


\section{MARgarida Lima Rego}

In Wood's own words, ' $[t]$ he main policy underlying transaction set-off is that a creditor should not be able to claim payment for something which he has not done in breach of his obligation to the debtor.' ${ }^{42}$ However, '[w] hether a debtor may set off a cross-claim arising out of the transaction against his creditor's primary claim where the creditor is not in default is unclear.' ${ }^{143}$ The basis of transaction set-off seems to be fairness to the debtor. In the situation under analysis we merely wish to prevent $\mathrm{P}$ from claiming the full contract price, even though he is in no way in breach of contract. It is my belief that in this case transaction set-off should be available to $R$, given that the same policy of avoiding the over-imbursement of the creditor is at play. ${ }^{144}$

Of course, in the situation under analysis, transaction set-off would be available to $\mathrm{R}$ merely as a defence, not as a cross-claim. There would be no need for the recognition of an independent claim by $\mathrm{R}$ over P's savings and profits; R's remedy only makes sense as a cap to his contractual debt to P. In other words, $\mathrm{R}$ does not owe $\mathrm{P}$ the full contract price, subject to a separate and independent cross-claim which would involve a deduction to that full contract price if exercised in the same action. What $\mathrm{R}$ owes $\mathrm{P}$ is a single amount which has already been subject to the deduction in question. This deduction can be operated in court or by way of self-help, therefore R shall not have to pay the full contract price whether the case is dealt with judicially or extra-judicially.

Finally, there is still the matter of the burden of proof to be dealt with. Clearly all $\mathrm{P}$ must do is claim his right to the contract price. This much stems from the need to protect his contractual expectations. It will be up to $\mathrm{R}$ to prove that he has the right to the deduction in question, that is, it will be up to him to satisfy the court that, due to his having notified $\mathrm{P}$ of his loss of interest, $P$ has been released from performing his part of the contract. $R$ must then provide evidence as to P's alleged saved expenses and as to any profit he has otherwise made. Essentially, P's release from performing his part of the contract must not injure his previous standing; hence this protection shall extend to every substantive and procedural aspect of the case.

142 Same book 107.

143 Same book 120.

144 See Bankes v Jarvis [1903] 1 KB 549 (CA) and Canada Southern Rly Co v Michigan Central Railroad Co (1984) 45 OR (2d) 257 for some examples of transaction set-off at its most liberal. 


\section{WHAT IF IT IS CHEAPER TO SUPPLY THE SERVICES THAN NOT TO?}

Let us take the White o Carter case itself. In this case the contract between the advertisers and the garage owners was a renewal contract. According to Diamond, ${ }^{145}$ this meant that at the time of contracting the advertisements had already been exhibited for the previous three years and were probably still out on the litter bins. Therefore, it was more than likely that the new contract was for the advertisers nearly all pure profit. Conversely, if they were made to abstain from any further performance, they would have to send people round withdrawing those advertisements. Regardless of whether this author has got the facts of this case right, it is certainly true that in certain contracts - particularly contracts of renewal - it is clearly cheaper to go ahead and render the agreed services than it is to abstain from such a supply. One has only to think of the case of contracts for the supply of water or electricity where the same sort of situation could occur.

In this type of situation, $\mathrm{P}$ would obviously not save any expenses by not rendering his services to $R$, hence the latter would still be liable for the full contract price - no deduction would take place. But should $\mathrm{P}$ be allowed to go ahead and perform in order to get the same amount of profit he was counting on? This is undoubtedly a very difficult question. On the one hand, one could say that whenever this is the case P's expectations would necessarily be injured by R's right to renounce the benefit of the contract, in which case the latter should not be recognised. Perhaps the outcome of the White \& Carter case was a fair one after all!

Alternatively, one could allow $\mathrm{R}$ to reject the benefit of the contract, provided he indemnified $\mathrm{P}$ for his loss of profit. One could also argue that all the expenses connected to the cessation of P's supply of services should be borne entirely by him, given that generally speaking they are unavoidable, at some time or another, and should therefore be taken into consideration when he comes up with the contract price. At any rate in those cases where P's supply of services is actually potentially damaging to R's best interest it is my belief that the former should not be allowed to render them, whatever the consequences to himself. At this stage, however, all one can aspire is to call attention to this problem rather than attempt to solve it.

145 AL Diamond 'Commerce, customers and contracts' (1978) 11 MelULRev 563, $575-6$. 
In this dissertation I have set out to offer an alternative outlook on the decision of a contractual party to reject the benefit of the contract when he is no longer interested in the other party's performance. I have attempted to justify such course of action by putting forward an analysis of the situation that does not entail its characterisation as a breach of contract.

I have embarked on this project with the firm conviction that it is perfectly reasonable that someone may wish to secure a contractual right to a given service without at the same time promising that he will accept it when the time comes. I wished to find out exactly why one does not more often come across clear instances of that frame of mind when going over the existent case law. I was faced with a number of obstacles which I set about to overcome in order to promote the possibility of lawfully preventing another's performance.

The first of those obstacles was the widely spread suggestion that the common law imposes on the parties to a contract a duty to cooperate in order to facilitate the fulfilment of their bargain. After a thorough examination of the relevant leading cases it became apparent that the duty-based approach to cooperation originated in an improper overgeneralization of authority that gave rise to an unsuitably framed rule of construction. Indeed, the courts seemed to have failed to notice that there are other ways, over and above the making of a promise, of bringing about a certain desired action by another person.

The major shortcoming of the courts' line of reasoning seemed to be their constant emphasis on 'the bargain' as opposed to the parties' mutual promises - as if they were bound to fulfil 'it' rather than each other's reasonable expectations. Under the mistaken assumption that when concluding a contract the parties bind themselves to achieve one and the same end result, they have erroneously concluded that (a) the parties must have an unfettered right to perform their part of the deal free from interference - the negative side of cooperation; and that (b) they are under the obligation to do whatever it takes to accomplish that end result - the positive side of cooperation. This approach blatantly overlooks the fact that sometimes the recognition of a right to perform (and of its counterpart, the duty to cooperate) might be diametrically opposed to what the parties themselves had intended.

After exposing the fallacy behind this approach I have concluded Chapter One with the submission that, whereas each contractual party must have the duty to cooperate so as not to frustrate the other party's legitimate contractual expectations, when it comes to his own expectations that party is merely faced with a choice between two alternative courses of action, both of which are 
lawful: he may decide either to cooperate and fulfil his expectations or not to cooperate and suffer the consequences of his own inactivity. I have further submitted that, insofar as one's own contractual expectations are concerned, the concept of a 'burden' - rather than that of a duty - is much better suited to encapsulate the true meaning of the requirement of cooperation.

In Chapter Two I set myself the task of contesting two other popular but misconceived assumptions that stood in the way of my ultimate goal. The first of those assumptions was the common belief that a party's share in the contractual risk-allocation is restricted to the scope of his contractual promises. This assumption was easily set aside by making clear that there are more ways of taking a contractual risk other than the making of a promise, first and foremost that of resorting to the concept of condition.

Linking up with the previously outlined 'burden' analysis, I went on to explain that where one takes the risk that a certain event will take place, either (a) the occurrence of that event is for the other party's benefit, in which case bearing the risk means promising that it will happen; or (b) it is not for the other party's benefit, in which case bearing the risk means suffering the consequences of its non-occurrence without being excused from performing one's own part of the deal. It was my contention that in the latter type of situation the requirement of cooperation should be characterised as a potestative condition subsequent to P's duty to perform.

Rather than imposing duties of cooperation, this approach makes use of the concept of a burden. $\mathrm{R}$ has the discretionary power to cooperate with $\mathrm{P}$ and hold him to his promise. He has a choice either to do it and fulfil his own contractual expectations or not to do it and fail to earn his right to the services he bargained for whilst still being bound to pay the full contract price. To put it another way, he is free to renounce the benefit of the contract, but he must cooperate if he wishes to have it. It is as simple as that. However, at this point another obstacle stood before me: the widespread belief that in order for $\mathrm{P}$ to claim the full contract price he must earn it by actually performing his part of the contract. It is this conception that lies behind the courts' insistence on safeguarding P's alleged right to perform. His expectation to the full contract price would otherwise not be met.

I have found this to be a deceptive form of backward reasoning that does not stand its ground once confronted with the product of a purposive approach to construction. It was my submission that in a large number of cases $\mathrm{P}$ will have no interest in actually performing his part of the contract beyond that of reflexively securing his right to the full contract price. He will therefore not have bargained for a right to perform, provided that right was not at stake. If one takes a fresh and open-minded look at each particular factual situation 


\section{Margarida Lima Rego}

one will undoubtedly reach the conclusion that $\mathrm{R}$ will not always have committed himself to cooperate. If one also concludes that $\mathrm{P}$ did not take the risk that R's cooperation would not materialise what must logically follow is that whenever $\mathrm{R}$ chooses not to act $\mathrm{P}$ must be released both from his duty to perform and from the need to earn the right to the full contract price. There is no other way of putting it.

The conditional approach to cooperation cannot provide $\mathrm{R}$ with an answer to his problem in those cases where $\mathrm{P}$ happens to be able to complete his part of the contract without R's cooperation and even against his will. In Chapter Three I tried to come up with an approach that would cover these cases as well. It then struck me that the whole affair of cooperation and the lack thereof was in fact quite incidental to the situation under analysis, because if $R$ is entitled to bargain for a right to reject and even prevent $P$ 's performance he should be allowed to do so regardless of whether the latter happens to require his cooperation in order to perform his part of the contract.

The problem with this assertion is that it must face an obstacle of considerable weight: in their obsession with the concept of repudiation, the courts have yet failed to realise that there is here an entirely separate issue that should be dealt with by means other than the application of the doctrine of anticipatory breach of contract. All through this dissertation I have argued that prevention should not be automatically characterised as a breach of contract in the shape of a repudiation. At this stage I needed to add that even in the presence of an unambiguous repudiation, insofar as the contract remains in force the subject of R's entitlement to reject and prevent P's performance must be handled as something entirely separate from that of the ineffectiveness of his attempted termination.

Indeed, just because R cannot be allowed to terminate the contract without P's assent it does not automatically follow that his conduct should be wholly devoid of effect. As well as attempting to terminate the contract, $R$ is letting $P$ know that he has lost all interest in the services he is about to provide. Those two aspects of one and the same conduct are different and should therefore be dealt with separately.

After having disposed of all the misleading assumptions, however, it became much clearer that the question that should be asked in any given factual situation is whether $\mathrm{P}$ has bargained for a right to perform. Where he has not, he should not be allowed to wholly disregard R's loss of interest only because he happens to be able to render his services without R's cooperation. Under those circumstances $R$ should be recognised both the right to renounce the benefit of the contract and the power to prevent $P$ from attempting to perform his part of the contract merely by informing him 
of his renunciation. I have called this purely conceptual remedy 'prevention by notification'.

Renouncing the benefit of a contract is something entirely different from attempting to terminate it. It means forsaking what one has bargained for whilst remaining bound to abide by one's contractual duties. Insofar as the contract is still in force, therefore, $\mathrm{R}$ is still prima facie liable for the full contract price. In Chapter Four I have focused on the proposition that under these circumstances $\mathrm{R}$ should nonetheless not be made to pay the full contract price. I have contended that he should be allowed to deduct from the contract price whichever sums $\mathrm{P}$ has saved or otherwise made as a result of his early discharge, so that the latter does not end up better off than he would have been had he duly performed his part of the contract. It is the general policy against over-compensation at work.

I have put forward that $\mathrm{R}$ should resort to the technical device of the transaction set-off and use it as a defence to P's claim to the full contract price made by way of an action in debt. This amounts to an application of the doctrine of mitigation in fact. Even though there was no breach of contract proper, there is definitely an element of compensation in the claimant's remedy in that the award of the contract price is aimed at putting $\mathrm{P}$ in the position he would have been in had he duly supplied his services to $R$, rather than at rewarding him for the actual performance of those services. Therefore, the expectation measure becomes relevant and so does the concept of loss, or the lack thereof. Should P have gone ahead and supplied his services to R, whatever he failed to save must not be taken into account; it must not be characterised as constituting an expense in any way related to performance of his contractual obligations. Moreover, where his conduct in attempting to 'perform' is detrimental, he should have to compensate $\mathrm{R}$ for any loss his 'performance' might have caused him.

It is my belief that a contracting party who decides to reject the benefit of the contract because he is no longer interested in the other party's performance would greatly benefit from a more nuanced understanding of the action for the agreed contract price. Such an approach would enable the courts to look beyond the existence of a claim in debt and take due notice of the relative interests of the parties to the contract, in order to arrive at a solution that provides each of them with the level of protection that matches their needs. The suggestion for an alternative outlook on the situation under scrutiny has not been made just for the sake of argument, rather it was offered in the hope of encouraging a more constructive understanding of the provision of services. 


\section{MARGARIDA LiMA REgo}

\section{BIBLIOGRAPHY*}

JN Adams 'The economics of good faith in contract' (1995) 8 JCL 126

* IN Adams and R Brownsword Key Issues in Contract (Butterworths London 1995)

* CF Almeida 'Recusa de cumprimento declarada antes do vencimento' in Estudos em Mernória do Professor Doutor João de Castro Mendes (Lex Lisbon 1995) 289-317

Anon 'Contracts - implied promise to cooperate - torts - negligent interference with contract' (1927-28) 41 HarvLRev 398

* Anon 'Unilateral contract law - an analysis in terms of conditions' (1933) 33 CollRev 463

* Anon 'Contract:: anticipatory breach and mitigation of damages' (1962) 233 Law Times 381

* Anon 'Anticipatory breach: right of plaintiff to perform' (1963-66) 2 AdellRev 103

* PS Atiyah An Introduction to the Law of Contract (5th edn OUP Oxford 1995)

* AJ Bateson 'The duty to co-operate' [1960] JBL 187

$\mathrm{H}$ Beale and T Dugdale 'Contracts between businessmen: planning and the use of contractual remedies' (1975) 2 BrJLSoc 45

* HG Beale (ed) Chitty on Contracts (28th edn Sweet \& Maxwell London 1999)

* J Beatson and D Friedmann (edd) Good Faith and Fault in Contract Law (OUP Oxford 1997)

P Birks 'The concept of a civil wrong' in DG Owen (ed) Philosophical Foundations of Tort Law (corrected paperback edn OUP Oxford 1997) 29

* P Birks 'Rights, wrongs and remedies' (2000) 20 OJLS 1

MG Bridge 'Does Anglo-Canadian contract law need a doctrine of good faith?' (1984) 9 CanBLJ 385

* MG Bridge 'Mitigation of damages in contract and the meaning of avoidable loss' (1989) 105 LQR 398

MG Bridge 'Good faith in commercial contracts' in R Brownsword, NJ Hird and G Howells (edd) Good Faith in Contract: Concept and Context (Dartmouth Publishing Co Aldershot 1999) 139

$\mathrm{R}$ Brownsword 'Towards a rational law of contract' in T Wilhelmsson (ed) Perspectives of Critical Contract Law (Dartmouth Publishing Co Aldershot 1993) 241

* R Brownsword " "Good faith in contracts" revisited' (1996) 49 CLP 111

$\mathrm{R}$ Brownsword 'From co-operative contracting to a contract of co-operation' in D Campbell and $\mathrm{P}$ Vincent-Jones (edd) Contract and Economic Organisation (Dartmouth Publishing Co Aldershot 1996) 14

R Brownsword 'Contract law, co-operation and good faith: the movement from static to dynamic market-individualism' in S Deakin and J Michie (edd) Contract, Co-operation, and Competition (OUP Oxford 1997) 255

* R Brownsword, NJ Hird and G Howells (edd) Good Faith in Contract: Concept and Context (Dartmouth Publishing Co Aldershot 1999)

R Brownsword 'Positive, negative, neutral: the reception of good faith in English contract law' in R Brownsword, NJ Hird and G Howells (edd) Good Faith in Contract: Concept and Context (Dartmouth Publishing Co Aldershot 1999) 13

* A Burrows The Law of Restitution (Butterworths London 1993)

* A Burrows Understanding the Law of Obligations. Essays on Contract, Tort and Restitution (Hart Publishing Oxford 1998)

${ }^{*}$ An asterisk denotes works cited. 
NO RIGHT TO PERFORM A CONTRACT?

* A Burrows Remedies for Torts and Breach of Contract (2nd edn Butterworths London 1994)

* JF Burrows 'Contractual co-operation and the implied term' (1968) 31 MLR 390

* JF Burrows 'Implied terms and presumptions' (1968) NZULRev 121

S) Burton 'Breach of contract and the common law duty to perform in good faith' (1980) 94 HarvLRev 369

D Campbell and P Vincent-Jones (edd) Contract and Economic Organisation (Dartmouth Publishing Co Aldershot 1996)

D Campbell 'The relational constitution of the discrete contract' in D Campbell and P VincentJones (edd) Contract and Economic Organisation (Dartmouth Publishing Co Aldershot 1996) 40

D Campbell "The relational constitution of contract and the limits of "economics": Kenneth Arrow on the social background of markets' in S Deakin and J Michie (edd) Contract, co-operation, and competition (OUP Oxford 1997) 307

* L Carroll Alice's Adventures in Wonderland in RL Green (ed) The Works of Lewis Carroll (Spring Books London 1965)

* JW Carter Breach of Contract (2nd edn Sweet \& Maxwell London 1991)

* JW Carter and GJ Tolhurst 'The new law on implied terms' (1996) 11 JCL 76

* JW Carter and GJ Tolhurst 'Implied terms: refining the law' (1997) 12 JCL 152

* JW Carter, A Phang and SY Phang 'Performance following repudiation: legal and economic interests' (1999) 15 JCL 97

H Collins 'Implied duty to give information during performance of contracts' (1992) 55 MLR 556

$\mathrm{H}$ Collins 'The transformation thesis and the ascription of contractual responsibility' in T Wilhelmsson (ed) Perspectives of Critical Contract Law (Dartmouth Publishing Co Aldershot 1993) 293

H Collins 'Good faith in European contract law' (1994) 14 OJLS 229

$\mathrm{H}$ Collins 'Competing norms of contractual behaviour' in D Campbell and P Vincent-Jones (edd) Contract and Economic Organisation (Dartmouth Publishing Co Aldershot 1996) 67

* H Collins The Law of Contract (3rd edn Butterworths London 1997)

* Contracts and Commercial Law Reform Committee 'The rule in White \& Carter (Councils) Ltd v McGregor' - a report presented to the New Zealander Minister of Justice on 5 May 1983 (New Zealand Law Society)

AL Corbin 'Offer and acceptance, and some of the resulting legal relations' (1917) 26 YaleLJ 169

* AL Corbin 'Conditions in the law of contract' (1919) 28 YaleLj 739

* AM Cordeiro Da Boa Fé no Direito Civil (reprint Almedina Coimbra 1997)

WR Cornish, R Nolan, J O'Sullivan and G Virgo (edd) Restitution: Past, Present and Future (Hart Publishing Oxford 1998)

GP Costigan 'Conditions in contracts' (1907) 7 ColLRev 151

* GP Costigan The Performance of Contract: a Summary of Conditions in Contracts and Impossibility of Performance (TH Flood Chicago 1911)

* WED Davies 'Anticipatory breach and mitigation of damages' (1960-62) 5 UWAusLRev 576

* S Degeling 'Carer's claims: unjust enrichment and tort' [2000] RLR 172

* F Dawson 'Metaphors and anticipatory breach of contract' [1981] CLJ 83

JP Dawson 'The self-serving intermeddler' (1973-74) 87 HarvLRev 1409

$S$ Deakin and J Michie (edd) Contract, Co-operation, and Competition (OUP Oxford 1997)

$S$ Deakin, C Lane and F Wilkinson 'Contract law, trust relations and incentives for co-operation: a comparative study' in S Deakin and J Michie (edd) Contract, Co-operation, and Competition (OUP Oxford 1997) 105 


\section{Margarida lima Rego}

* AL Diamond 'Commerce, customers and contracts' (1978) 11 MelULRev 563, 574-6

MA Eisenberg 'The bargain principle and its limits' (1981-82) 95 HarvLRev 741

* RL Faria A Mora do Credor (Lex Lisboa 2000)

EA Farnsworth 'Disputes over omission in contracts' (1968) 68 ColLRev 860

EA Farnsworth 'Good faith in contract performance' in J Beatson and D Friedmann (edd) Good Faith and Fault in Contract Law (OUP Oxford 1997) 153

* EA Farnsworth Changing your Mind: the Law of Regretted Decisions (YaleUP London New Haven 1998)

* ADM Forte (ed) Good Faith in Contract and Property (Hart Publishing Oxford 1999)

* Fourth Annual Conference of the JCL on 'Good faith and fairness in commercial contract law' (1994) 7 JCL and (1995) 8 JCL

* D Friedmann 'Good faith and remedies for breach of contract' in J Beatson and D Friedmann (edd) Good Faith and Fault in Contract Law (OUP Oxford 1997) 399

D Friedmann 'The efficient breach fallacy' (1989) 18 JLegSt 1

* MP Furmston 'The case of the insistent performer' (1962) 25 MLR 364

* MP Furmston Cheshire, Fifoot \& Furmston's Law of Contract (13th edn Butterworths London 1996)

* WM Gloag The Law of Contract: a Treatise on the Principles of Contract in the Law of Scotland (2nd edn Caledonian Books Collieston 1985)

CJ Goetz and RE Scott 'The mitigation principle: toward a general theory of contractual obligation' (1983) 69 VaLRev 967

* R Goode 'The concept of good faith in English law' (Centro di Studi e Richerche di Diritto Comparato e Straniero, Saggi, Conferenze e Seminari 2, Rome 1992)

* AL Goodhart 'Measure of damages when a contract is repudiated' [1962] 78 LQR 263

JC Gulotta 'Anticipatory breach - a comparative analysis' (1976) 50 TulLRev 927

* R Harrison Good Faith in Sales (Sweet \& Maxwell London 1997)

* WN Hohfeld 'Some fundamental legal conceptions as applied in judicial reasoning' (1913) 23 YaleLJ 16

* OW Holmes The Common Law (Dover Publications New York 1991)

AH Hudson 'Prorating in the English Law of frustrated contracts' (1968) 31 MLR 535

TH Jackson "Anticipatory repudiation" and the temporal element of contract law: an economic inquiry into contract damages in cases of prospective nonperformance' (1978) 31 StanLRev 69

H Kötz 'Towards a European civil code: the duty of good faith' in P Cane and J Stapleton (edd) The Law of Obligations - Essays in Celebration of John Fleming (OUP Oxford 1998) 243

* O Lando and H Beale Principles of European Contract Law (Kluwer Law International The Hague London Boston 2000)

* K Larenz Lehrbuch des Schuldrechts I (14th edn CH Beck'sche Verlagsbuchhandlung Munich 1987)

* K Larenz and M Wolf Allgemeiner Teil des bürgerlichen Rechts (8th edn CH Beck Munich 1997)

$R$ Lewis 'Contracts between businessmen: reform of the law of firm offers and an empirical study of tendering practices in the building society' (1982) 9 JLSoc 153

E Lomnicka 'Unreasonable termination and mitigation' (1983) 99 LQR 495

S McCracken The Banker's Remedy of Set-off (2nd edn Butterworths London 1998)

* JB Machado 'Risco contratual e mora do credor' (1985) 116 RJL 194

E McKendrick 'Good faith: a matter of principle?' in ADM Forte (ed) Good Faith in Contract and Property (Hart Publishing Oxford 1999) 39 


\section{NO RIGHT TO PERFORM A CONTRACT?}

- RG McKerron 'Effect of election not to accept anticipatory repudiation of contract: White \& Carter v McGregor' (1962) 79 SALJ 309

H McLean 'Contract conditions - when wrongdoers may take advantage' [1988] CLJ 343

IR Macneil 'Efficient breach of contract: circles in the sky' (1982) 68 VaLRev 947

IR Macneil 'Contracts: adjustment of long-term economic relations under classical, neoclassical, and relational contract law' (1978) 72 NwULRev 854

- M Mark Chalmers' Sale of Goods (18th edn Butterworths London 1981)

- AF Mason 'Contract, good faith and equitable standards in fair dealing' [2000] 116 LQR 66

K Mason "Commentary on "Conduct after breach: the position of the party not in breach" " (1991) 3 JCL 218

- C Mitchell 'Subrogation, unjust enrichment and remedial flexibility' [1998] RLR 144

- JL Montrose 'Conditions, warranties, and other contractual terms' (1937) 15 CanBarRev 309

- M Mustill 'Anticipatory breach of contract: the common law at work' in Butterworth Lectures 1989-90 (Butterworths London 1990) 1

B Nicholas 'Rules and terms - civil law and common law' (1974) 48 TulLRev 946

* PM Nienaber 'The effect of anticipatory repudiation: principle and policy' [1962] CLJ 213

- JF O'Connor Good Faith in English Law (Dartmouth Publishing Co Aldershot 1990)

* JM Paterson 'Terms implied in fact: the basis for implication' (1998) 13 JCL 103

EW Patterson 'The apportionment of business risks through legal devices' (1924) 24 CollRev 335

* EW Patterson 'Constructive conditions in contract' (1942) 42 CollRev 903

* E Peden ' "Cooperation" in English contract law - to construe or imply?' (2000) 16 JCL 56

* ML Pereira Conceito de Prestação e Destino da Contraprestação (Almedina Coimbra 2001)

* ABL Phang 'Implied terms revisited' [1990] JBL 394

* ABL Phang 'Implied terms in English law - some recent developments' [1993] JBL 242

* ABL Phang 'Implied terms again' [1994] JBL 255

* F Pollock Principles of Contract (9th edn Stevens \& Sons London 1921)

* RJ Pothier Traité des Obligations I (nouvelle édn Thomine et Fortic Paris 1821)

$R$ Powell 'Good faith in contracts' (1956) 9 CLP 16

* LJ Priestley 'Conduct after breach: the position of the party not in breach' (1990-91) 3 JCL 218

TD Rakoff "Implied terms: of "default rules" and "situation sense" ' in J Beatson and D Friedmann (edd) Good Faith and Fault in Contract Law (OUP Oxford 1997) 191

B Reiter and J Swan 'Contracts and the protection of reasonable expectations' in B Reiter and J Swan (edd) Studies in Contract Law (Butterworths Toronto 1980) 6

* FAC Sá Direito ao Cumprimento e Direito a Cumprir (Almedina Coimbra 1997)

* R Schmidt Die Obliegenheiten (Versicherungswissenschaft Karlsruhe 1953)

* K Scott 'Contract - Repudiation - Performance by innocent party' [1962] CLJ 12

* JC Silva Cumprimento e Sanção Pecuniária Compulsória (reprint 2th edn SBFDUC Coimbra 1997)

JE Stannard 'Frustrating delay' (1983) 46 MLR 738

* J Steyn 'The role of good faith and fair dealing in contract law: a hair-shirt philosophy' [1991] Denning LJ 131

J Steyn 'Contract law: fulfilling the reasonable expectations of honest men' (1997) 113 LQR 4.3

* SJ Stoljar 'Prevention and co-operation in the law of contract' (1953) 31 CanBarRev 231

SJ Stoljar 'The contractual concept of condition' (1953) 69 LQR 485 


\section{MARGARIDA LIMA REgo}

* SI Stoljar 'Some problems of anticipatory breach' (1974) 9 MelULRev 355

RS Summers 'The conceptualisation of good faith in American contract law: a general account' in R Zimmermann and S Whittaker (edd) Good Faith in European Contract Law (CambridgeUP Cambridge 2000) 118

* E Tabachnik 'Anticipatory breach of contract' [1972] 25 CLP 149

G Teubner 'Piercing the contractual veil? The social responsibility of contractual networks' in T Wilhelmsson (ed) Perspectives of Critical Contract Law (Dartmouth Publishing Co Aldershot 1993) 211

* G Teubner 'Legal irritants: good faith in British law or how unifying law ends up in new divergencies' (1998) 61 MLR 11

* GH Treitel 'Fault in the common law of contract' in B Maarten and I Brownlie (edd) Liber Amicorum for the Rt Hon Lord Wilberforce (OUP Oxford 1987) 185

* GH Treitel Remedies for Breach of Contract: a Comparative Account (repr pbk OUP Oxford 1991)

GH Treitel Frustration and Force Majeure (Sweet \& Maxwell London 1994)

* GH Treitel The Law of Contract (10th edn Sweet \& Maxwell London 1999)

DMW 'Contract - Repudiation - Remedy' [1962] JurRev 61

SM Waddams 'Good faith, unconscionability and reasonable expectations' (1995) 9 JCL 55

* S Whittaker 'How does french law deal with anticipatory breach of contract?' (1996) 45 ICLQ 662

* S Whittaker 'Performance of another's obligation: French and English law contrasted' (2000) OUCLF 7 at ouclf.iuscomp.org

J Wightman 'Reviving contract' (1989) 52 MLR 115

J Wightman 'Good faith and pluralism in the law of contract' in R Brownsword, NJ Hird and G Howells (edd) Good Faith in Contract: Concept and Context (Dartmouth Publishing Co Aldershot 1999) 41

T Wilhelmsson (ed) Perspectives of Critical Contract Law (Dartmouth Publishing Co Aldershot 1993)

T Wilhelmsson 'Questions for a critical contract law - and a contradictory answer: contract as social cooperation' in T Wilhelmsson (ed) Perspectives of Critical Contract Law (Dartmouth Publishing Co Aldershot 1993) 9

* GL Williams 'Language and the law - IV' [1945] 61 LQR 384

* R Williams 'Preventing unjust enrichment' [2000] RLR 492

* PR Wood English and International Set-off (Sweet \& Maxwell London 1989)

* R Zimmermann The Law of Obligations: Roman Foundations of the Civilian Tradition (OUP Oxford 1996)

* R Zimmermann and S Whittaker (edd) Good Faith in European Contract Law (CambridgeUP Cambridge 2000)

K Zweigert and H Kötz [T Weir (tr)] An Introduction to Comparative Law (3rd edn OUP Oxford 1998) 


\section{ÍNDICE}

Margarida Lima Rego, No right to perform a contract?..........................................................

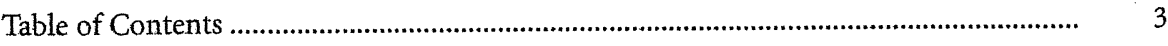

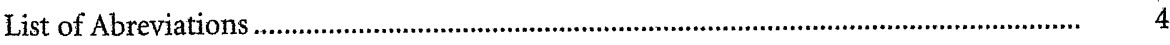

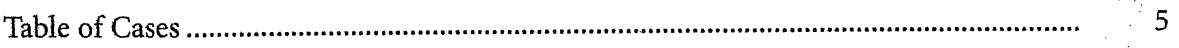

Preliminary Chapter......................................................................................................... 10

Chapter I - The promissory approach to cooperation ......................................................... 15
A. A duty to cooperate? .............................................................................................. 15

B. Protecting the parties' reasonable expectations........................................................ 18

C. Hidden assumptions............................................................................................. 21

D. An improper overgeneralisation of authority ..................................................... 25

E. Discharge through lack of cooperation.................................................................... 26

F. The concept of a 'burden' ....................................................................................... 28

Chapter II - A conditional approach to cooperation ........................................................ 30
A. Contractual risk-allocation .................................................................................. 30

B. Introducing the concept of condition...................................................................... 32

C. A discretionary power to cooperate? ....................................................................... 34

D. The obstacle: a right to perform ……..................................................................... 34

E. The hidden assumption strikes again ..................................................................... 36

F. P's expectation to the full contract price ......................................................... $\quad 37$

G. What exactly is at stake here? ......................................................................... 40

$\mathrm{H}$. What the parties have truly promised to do ........................................................ 41

Chapter III - The right to reject the benefit of the contract ...................................... $\quad 42$

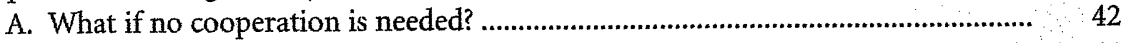

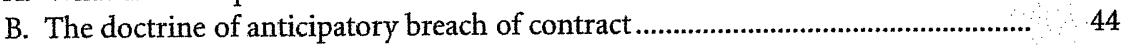

C. Missing the point .......................................................................................... 45

D. Yet another hidden assumption ..................................................................... 49

E. The right to renounce the benefit of a contract .................................................... $\quad 50$

F. Prevention by notification................................................................................... 52

G. 'No legitimate interest, financial or otherwise' .................................................... 54

Chapter IV - Deducting from the full contract price........................................................ 59

A. The need for a deduction .................................................................................. 59

B. How to deduct: mitigation …………............................................................... 61

C. The way to do it: transaction set-off....................................................................... 63

D. What if it is cheaper to supply the services than not to? ....................................... 65 


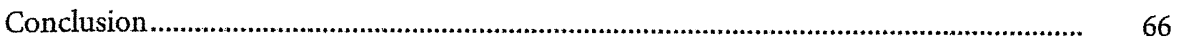

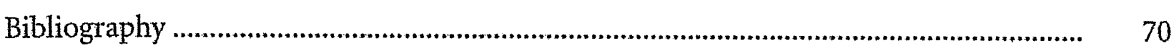

Normas redactoriais......................................................................................

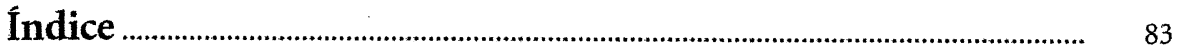

